\title{
SEJARAH EKONOMI NEGARA BRUNEI DARUSSALAM, 1906-2011 (ECONOMIC HISTORY OF BRUNEI DARUSSALAM, 1906-2011)
}

\author{
Abdul Malik Kamis \& Thirunaukarasu Subramaniam \\ Department of Southeast Asian Studies \\ Faculty of Arts and Social Sciences \\ University of Malaya \\ (hakilam04@yahoo.co.uk)
}

\begin{abstract}
The Brunei economy has gone through significant changes throughout the period from 1900 to present. The resources as well the economic activity had gone through tremendous changes in their contribution towards the national income. As such, this paper will explain the background and the history of Brunei economy. It expounds the history of Brunei economy before 1906 or the traditional period, the Brunei economy during the British Resident administration (1906-1941), the Brunei economy during the Japanese occupation (1941-1945), the Brunei economy during the administration of British Resident (1946-1959), the Brunei economy during self-government (1959-1983) and finally the progress in Brunei economy post independence (1984-2011). Emphasis will be given to the development of oil and gas industry (oil sector) which plays an important role in the development of Brunei economy since its finding. Emphasis is also given to the contribution of the export from oil sector towards Brunei economy and its implications for the non-oil sector. This includes several economic resources that initially were main export commodities of Brunei which subsequently declined and no longer contribute towards the economy of Brunei. The trends of contribution for oil and non-oil sector to the Brunei economy is also analysed.
\end{abstract}

Keywords: Brunei, economy, history, 1906-2011, main commodity, oil and gas sector, percentage and gross domestic product (GDP). 


\section{Pengenalan}

Ekonomi Brunei seperti yang dimaklumi sangat bergantung kepada sektor minyak semenjak ia ditemui dan mula dieksport. Bagaimanapun ramai yang tidak mengetahui bahawa ekonomi Brunei sebelum minyak dan gas ditemui sangat bergantung kepada sumber dari hasil bumi dan laut iaitu dalam sektor pertanian, perhutanan, perlombongan dan pembuatan. Ekonomi Brunei pada zaman dahulu pernah berkembang dengan pesatnya dan mempunyai hubungan dagang dengan dunia luar. Manakala Kampong Ayer pernah menjadi pusat kegiatan ekonomi Brunei bagi perdagangan luar dan dalam negeri. Selain menikmati zaman kegemilangannya, Brunei juga pernah mengalami zaman kemerosotan yang begitu buruk dan hampir muflis kerana tidak mempunyai sistem kewangan yang teratur ditambah lagi dengan keadaan struktur pentadbiran tradisional yang diamalkan di Brunei dianggap begitu lemah. Walau bagaimapun setelah pemerintahan Residen British bermula pada 1906, pentadbiran kewangan Brunei telah berubah dan tersusun dan ekonomi Brunei semakin berkembang sehinggalah minyak dan gas ditemui. Ekonomi Brunei bagaimapun kembali lumpuh akibat dari pendudukan tentera Jepun di Brunei tetapi kembali pulih setelah tentera Jepun keluar pada tahun 1945. Setelah Residen British kembali memerintah Brunei, ekonomi Brunei semakin berkembang hasil dari sektor minyak. Ekonomi Brunei terus berkembang maju pada zaman berkerajaan sendiri dan zaman selepas kemerdekaan. Ekonomi Brunei sehingga sekarang dikuasai oleh sumber minyak dan gas. Sektor bukan minyak bagaimanapun masih diusahakan dan dikembangmajukan oleh kerajaan Brunei dengan menjalankan dasar mempelbagaikan ekonomi supaya ekonomi Brunei tidak bergantung sepenuhnya kepada sektor minyak. Dasar ini perlu dilaksanakan bagi mengelakkan terjadinya kegawatan ekonomi apabila berlaku kepupusan sumber dan kejatuhan teruk harga minyak dan gas suatu hari nanti. Dasar mempelbagikan ekonomi juga menjadi agenda utama bagi menuju Wawasan Brunei 2035.

\section{Ekonomi Brunei Sebelum 1906}

Struktur pentadbiran Brunei sebelum Sistem Residen 1906 diperkenalkan adalah berbentuk struktur pentadbiran tradisional. Ini juga dikenali sebagai zaman tradisi. Ekonomi Brunei pada ketika itu begitu buruk dan hampir muflis kerana tidak mempunyai sistem kewangan yang teratur kerana perbendaharaan hanya diperkenalkan semasa Sistem Residen. Sultan dan 
pembesar-pembesar negeri ketika itu telah berhutang dengan menggadai hasil pendapatan negeri (Muhaimin Mohamed, 2011). Struktur pentadbiran tradisional yang diamalkan di Brunei dianggap begitu lemah dan kelemahan pentadbiran ini telah memberikan ruang kepada British yang datang ke Borneo untuk merampas wilayah-wilayah Brunei ketika itu.

Perdagangan adalah menjadi asas ekonomi yang penting bagi Brunei pada ketika itu. Perdagangan Brunei terbahagi kepada dua iaitu perdagangan antarabangsa dan perdagangan tempatan. Hasil-hasil bumi dan laut Brunei ketika itu adalah getah, sagu, kapur barus, kayu kayan, lilin lebah, sarang burung, antimoni, emas, garam laut, ikan, kulit penyu, tripang, sayur-sayuran dan binatang ternakan (Tassim Abu Bakar, 2012). Ini menjadikan Kampong Ayer yang menjadi pusat pentadbiran Brunei ketika itu menjadi tempat persinggahan para pedagang dan laluan bagi kapal-kapal pedagang dari Barat dan Timor.

\section{Perdagangan Antarabangsa Zaman Tradisi Brunei}

Brunei menjalinkan hubungan antarabangsa dengan beberapa pusat perdagangan maritim negara luar, di antaranya yang terdapat di Benua China, Eropah, Arab dan negara-negara di kawasan rantau ini seperti Melaka, Jawa, Siam, Champa, Patani, Sumatera dan Kemboja. Urusan perdagangan antarabangsa Brunei digerakkan dan didominasi oleh golongan atasan yang memegang tampuk kuasa dan kroni-kroninya seperti sultan, golongan pengiran-pengiran dan wakil-wakil sultan.

Hubungan ekonomi Brunei dengan China mula terjalin apabila seorang saudagar Cina Islam bernama P'u Lu-Hsien yang telah ke Brunei pada tahun 977 Masihi (Tassim Abu Bakar, 2012). Ketika itu perdagangan antara kedua buah negara dilakukan secara terus. Hubungan yang erat ini yang berlaku semasa Dinasti Sung (960 - 1279) berterusan sehingga abad ke 15 dan 16 Masihi. Brunei ketika itu memasarkan barangan tempatan seperti kapur barus, lilin, kulit penyu dan lain-lain terus ke negeri China. Pedagangpedagang China pula membawa barang-barang dagangan seperti tembikar, barangan perak, emas, kain sutera, kain tenunan, dan lain-lain. Sistem jual-beli ketika itu ialah dengan mengamalkan sistem "Barter Trade" iaitu pertukaran barang. Oleh itu barangan yang dibawa oleh pedagang-pedagang dari China akan menukar barang-barang mereka kepada barangan-barangan kepunyaan pedagang-pedagang tempatan. Brunei pada ketika itu juga terkenal dengan sebuah negara yang membekal kapur barus atau Mountain of Champor. Ini kerana perdagangan kapur barus dibuat secara meluas. 
Manakala hubungan ekonomi Brunei dengan Eropah pernah ditulis oleh Antonio Pigafetta yang melawat Brunei pada tahun 1521 Masihi (Tassim Abu Bakar, 2012). Beliau menceritakan bahawa Brunei adalah sebuah negara kaya kerana mempunyai hasil-hasil bumi yang diperdagangkan seperti kapur barus, kayu manis, halia, tembikai, timun, labu, sarang lebah, kubis, daging kerbau, daging rusa dan gading gajah. Pedagang Sepanyol dan Portugis tertarik dengan kepesatan dan perkembangan perdagangan di Pelabuhan Brunei.

Hubungan ekonomi Brunei dengan Arab pula terjalin apabila Brunei menjadi tempat persinggahan pedagang-pedagang Arab yang berlayar ke Benua China. Selain berniaga, tujuan pedagang-pedagang Arab adalah untuk menyebarkan agama Islam. Ini termasuklah Sultan Syarif Ali, iaitu Sultan Brunei yang ketiga. Beliau adalah seorang pedagang Arab yang juga penyebar agama Islam berasal dari Taif, Arab Saudi dan kemudiannya diangkat menjadi Sultan Brunei yang ketiga. Ini menguatkan lagi hubungan dagang antara Brunei dengan Arab. Pedagang-pedagang Arab juga memainkan peranan penting dalam hubungan perdagangan Brunei dengan China kerana semasa Brunei menghantar rombongan ke Benua China pada tahun 977 Masihi, ia disertai oleh orang-orang Arab (Tassim Abu Bakar, 2012).

Hubungan dagang Brunei dengan rantau ini memang begitu erat dan telah lama terjalin seperti Kerajaan Majapahit, Kerajaan Melaka dan lain-lain (Tassim Abu Bakar, 2012). Rantau ini, membekalkan penduduk Brunei yang tinggal di Kampong Ayer dengan kapur barus, kulit penyu, sagu, lada hitam, rotan dan sebagainya. Sebenarnya penduduk Brunei menjadi orang tengah yang mana barang-barang tersebut akan didagangkan dengan pedagangpedagang dari tempat lain seperti China, Eropah dan Arab untuk mendapatkan barang-barang lain seperti pakaian, pinggan mangkuk, pisau dan sebagainya. Ia memberikan gambaran bahawa Kampong Ayer memang terkenal sebagai pusat perdagangan di rantau ini yang menarik pedagangpedagang dari Benua China, Eropah dan Arab. Ini bermakna penduduk Brunei mempunyai ilmu perniagaan yang baik sehingga dapat menjadi orang tengah dan menjadikan Kampong Ayer sebagai pusat perdagangan. Hasil dari hubungan dagang ini, Brunei menjadi pengeksport barang-barang seperti kapur barus, kulit penyu, lilin, gading gajah, kayu gaharu, sagu, lada hitam, rotan dan mutiara.

\section{Perdagangan Tempatan Zaman Tradisi Brunei}

Kegiatan ekonomi tempatan di zaman tradisi Brunei terbahagi kepada dua. Pertama ialah kegiatan dari perdagangan hasil bumi dan laut. Kedua dari hasil 
pembuatan. Dalam sistem pentadbiran di zaman tradisi Brunei, sultan mewakilkan beberapa pembesar negara untuk mengurus pentadbiran di beberapa kawasan jajahan pada masa itu. Wakil-wakil ini juga bertanggung jawab untuk mengurus pendapatan hasil di tempat-tempat mereka. Hasil-hasil dari kawasan jajahan dan pedalaman akan dibawa ke pusat pentadbiran negara iaitu Kampong Ayer.

Jajahan di sebelah barat Pulau Borneo mengeluarkan hasil hutan, pertanian dan galian. Manakala di sebelah timur Pulau Borneo pula menghasilkan sumber laut dan pertanian. Penduduk tempatan akan menghantar hasil-hasil tersebut ke pusat pentadbiran di Kampong Ayer. Perdagangan ini adalah bersifat tempatan dan kebanyakan mereka yang terlibat terdiri daripada penduduk tempatan. Ini membuatkan Kampong Ayer sebagai satu pusat perdagangan yang pesat. Mereka yang terlibat dalam perdagangan tempatan ini adalah pengalu dan padian. Pengalu biasa terdiri dari kaum lelaki manakala padian terdiri dari kaum wanita. Peranan pengalu dan padian adalah menjadi pedagang runcit dan pengedar atau orang tengah ke kawasan petempatan seperti Kampong Ayer dan kawasan pedalaman.

Pengalu menjalankan perdagangan di kawasan pedalaman dengan menggunakan sungai-sungai. Untuk menjalankan perniagaan ini Pengalu menggunakan perahu besar berdinding dan beratap segi empat. Mereka biasanya mencari barang-barang dagangan sehingga ke pesisiran Teluk Brunei dengan membeli secara pajak daripada pembekal berkenaan. Selepas itu mereka pergi ke kawasan-kawasan pedalaman dan pesisiran sungai-sungai untuk menukar barang tersebut dengan hasil-hasil tanaman daripada penduduk di situ yang terdiri dari masyarakat Bisaya, Iban, Murut dan Penan.

Padian pula menjalankan perniagaan dengan berkayuh menggunakan "gubang" atau sampan. Mereka biasanya berpusat di suatu tempat dan jarak mereka menjalankan perniagaan di sekitar perumahan Kampong Ayer. Mereka biasanya menjual barang-barang keperluan harian seperti beras, sagu, ikan, sayur, buah-buahan, dan kuih-muih. Semasa menjalankan perniagaan, Padian memakai 'Siraung' atau penutup kepala yang diperbuat daripada daun nipah. Bentuk siraung adalah seperti tudung saji dan ia dipakai sebagai pelindung daripada panas dan hujan.

Dalam bidang pembuatan pula, di zaman tradisi Kampong Ayer memang dikenali dengan perusahaan pembuatan seperti tukang emas, perak dan tembaga. Ini adalah satu kegiatan ekonomi bagi golongan bawahan. Perusahaan-perusahaan ini telah bermula sejak zaman Sultan Bolkiah lagi. Selain itu bertenun kain juga merupakan salah satu kegiatan ekonomi masyarakat Kampong Ayer yang penting ketika itu. Mereka bertenun kain di 
rumah-rumah mereka. Perusahaan bertenun ini telah wujud sejak abad ke-13 lagi di mana sultan selalunya menghadiahkan kain tenunan kepada pedagangpedagang dari China. Kewujudan perusahaan tenunan juga berdasarkan kepada pemakaian songket benang emas oleh penduduk Brunei serta melalui hubungan sultan dengan pedagang-pedagang China. Pakar tenun pada mulanya dibawa dari China untuk menetap di Brunei bagi membuat pakaian sultan, permaisuri dan anak-anak diraja. Ilmu tenunan ini telah dipindahkan kepada penduduk Brunei sehingga mereka mampu membuat tenunan dan reka bentuk tersendiri.

\section{Ekonomi Brunei Semasa Pentadbiran Residen British (1906-1941)}

Perjanjian 1905/1906 (Muhaimin Mohamed, 2011) adalah satu keputusan politik yang diambil oleh Sultan Hashim bagi melindungi kedaulatan Brunei yang terancam akibat daripada tindakan James Brooke yang merampas wilayah-wilayah Brunei. Keputusan ini adalah satu keputusan yang bijak kerana dengan adanya Sistem Residen di Brunei, ia memantapkan lagi sistem pentadbiran Brunei yang beralih dari tradisional kepada sistem pentadbiran moden. Walau bagaimanapun, sistem pentadbiran Residen British menyebabkan Sultan tidak lagi mempunyai kuasa yang mutlak seperti dalam pentadbiran tradisi sebelumnya.

Pentadbiran Residen British di Brunei telah berjaya memberi nafas baru kepada kegiatan ekonomi Brunei kerana ia lebih terkawal dan melalui penyusunan semula. Tindakan awal yang dibuat oleh McArthur, Residen British yang pertama, dalam usaha untuk memulihkan ekonomi Brunei ketika itu ialah dengan membuat pinjaman sebanyak \$200 ribu dari Negeri-Negeri Melayu Bersekutu (NNMB). McArthur juga melaksanakan dua dasar utama dalam pentadbirannya, pertama, memperkenalkan satu sistem pentadbiran sekular yang tidak mengetepikan status quo masyarakat tradisi Melayu Islam dan bersesuaian dengan kepentingan sosioekonomi British; kedua, memudahkan segala kegiatan ekonomi peribumi dengan mengeksploitasi kekayaan alam yang sah dan dilindungi oleh undang-undang serta untuk memperoleh kekayaan dan keuntungan yang maksimum (Pg Khairul Rijal Pg Abdul Rahim, 2007). Tindakan seterusnya untuk memantapkan kewangan negara ialah dengan menetapkan matawang, reformasi cukai, meluluskan Akta Kastam dan meluluskan Undang-undang Tanah. Perbendaharaan juga diperkenalkan untuk pengurusan kewangan negara (Jiram Jamit, 2012, p. 126). 


\section{Sebelum Minyak Dijumpai}

Pada zaman pemerintahan Residen British di Brunei, sebelum minyak dijumpai, ekonomi Brunei secara keseluruhannya bergantung kepada sumber pertanian, perhutanan dan perlombongan. Eksport komoditi utama bagi sektor pertanian ialah ubar (Cutch), getah asli dan sagu. Brunei juga mengeluarkan getah jelutong dari sektor perhutanan. Manakala eksport komoditi utama bagi sektor perlombongan adalah arang batu.

Sektor pertanian menjadi elemen penting dalam usaha Residen British untuk menggerakkan ekonomi Brunei. Kawasan tanah di Brunei telah dibuka bagi membolehkan sektor pertanian dapat dilaksanakan yang juga menyebabkan pentadbiran yang berpusat di Kampong Air telah berpindah ke darat. Ubar ${ }^{1}$ adalah menjadi eksport pertama Brunei dalam sektor pertanian semasa pentadbiran Residen British seperti yang tertera dalam Jadual 1.

Jadual 1: Nilai Eksport Komoditi Utama Sektor Pertanian 1906-1941

\begin{tabular}{|c|c|c|c|}
\hline Tahun & Cutch & $\begin{array}{c}\text { Getah Asli } \\
\mathbf{( \$ )}\end{array}$ & $\begin{array}{c}\text { Sagu } \\
\mathbf{( \$ )}\end{array}$ \\
\hline 1906 & - & - & - \\
\hline 1907 & 44,000 & - & - \\
\hline 1908 & 69,579 & - & 11,918 \\
\hline 1909 & 232,498 & - & 14,753 \\
\hline 1910 & 228,361 & - & 20,811 \\
\hline 1911 & t.d & - & t.d \\
\hline 1912 & 224,802 & - & 33,010 \\
\hline 1913 & 207,729 & - & t.d \\
\hline 1914 & 205,483 & 1,160 & 37,229 \\
\hline 1915 & 237,400 & 60,103 & 31,317 \\
\hline 1916 & 285,400 & 142,711 & 21,697 \\
\hline 1917 & 330,700 & 248,919 & 31,140 \\
\hline 1918 & 361,501 & 174,868 & 80,920 \\
\hline 1919 & 304,249 & 243,569 & 84,512 \\
\hline 1920 & 355,300 & 214,733 & 43,764 \\
\hline 1921 & 241,740 & 82,217 & 73,757 \\
\hline 1922 & 172,600 & 91,104 & 39,354 \\
\hline 1923 & 238,000 & 363,200 & 27,725 \\
\hline 1924 & 176,490 & 387,794 & 23,840 \\
\hline 1925 & 234,000 & $1,318,217$ & 8,304 \\
\hline 1926 & 189,200 & $1,032,055$ & 9,293 \\
\hline 1927 & 202,840 & 892,627 & 12,214 \\
\hline 1928 & 179,104 & 581,265 & 12,897 \\
\hline 1929 & 185,802 & 742,999 & 21,797 \\
\hline 1930 & 220,080 & 377,927 & 3,594 \\
\hline 1931 & 194,457 & 161,204 & 8,669 \\
\hline 1932 & 195,465 & 104,899 & 4,581 \\
\hline 1933 & 123,757 & 236,249 & \\
\hline & & & \\
\hline & & & - \\
\hline
\end{tabular}




\begin{tabular}{|c|c|c|c|}
\hline 1934 & 162,861 & 671,970 & 2,526 \\
\hline 1935 & 177,910 & 576,159 & 6,265 \\
\hline 1936 & 172,743 & 790,703 & 14,029 \\
\hline 1937 & 212,239 & $1,240,995$ & 28,499 \\
\hline 1938 & 152,366 & 623,565 & 13,542 \\
\hline 1939 & 62,995 & 925,700 & 37,134 \\
\hline 1940 & 112,129 & $1,503,801$ & 102,592 \\
\hline 1941 & 97,500 & $1,758,824$ & 26,175 \\
\hline
\end{tabular}

Sumber : Jadual 2.2, dalam Pg Khairul Rijal Pg Abdul Rahim (2007, p. 26).

Nota $\quad:{ }^{*}$ t.d. - tiada data.

Kompeni Island Trading Syndicate telah melakar sejarah setelah diberikan konsesi daripada Kerajaan Brunei pada tahun 1900 (Muhaimin Mohamed, 2011) untuk mengusahakan perusahaan ubar. Ubar telah dieksport ke Amerika Syarikat, Perancis , Argentina, United Kingdom, Jepun dan China dan telah berjaya menggaji 300 orang penduduk Brunei pada tahun 1921 (Pg Khairul Rijal Pg Abdul Rahim, 2007). Dari Jadual 1, pendapatan dari eksport ubar telah meningkat secara drastik daripada $\$ 44,000$ pada tahun 1907 kepada $\$ 232,498$ pada tahun 1909. Pendapatan dari ubar terus meningkat dari setahun ke setahun dan buat pertama kali melepasi nilai \$300,000 pada tahun 1917. Manakala pada tahun 1918 telah tercatat pendapatan yang paling tinggi dalam sejarah pengeluaran ubar di Brunei dengan memperolehi $\$ 361,501$. Ini menjadikan ubar sebagai eksport utama Brunei yang paling banyak menyumbang kepada pendapatan hasil Brunei iaitu dari tempoh 1907 hingga 1922. Walau bagaimanapun pendapatan ini tidak mampu bertahan lama apabila nilai eksport yang diperolehi kurang dari \$300,000 pada tahun 1921. Semenjak itu hasil pendapatan dari eksport ubar mengalami turun naik dan semakin merosot, ubar menjadi komoditi kedua terpenting selepas getah asli dari tahun 1923 hingga 1931.

Selain itu hasil getah juga menjadi sumber ekonomi Brunei sebelum penemuan minyak. Penanaman pokok-pokok getah mula dilakukan pada tahun 1908. Oleh kerana permintaan getah meningkat di peringkat antarabangsa berikutan dengan bertambahnya pengeluaran bahan-bahan industri yang diperbuat daripada getah, ramai pelabur Barat telah datang ke Brunei untuk mengusahakan tanaman ini. Maka dengan itu, ladang getah yang dibuka mula meningkat yang mana pada tahun 1911 sahaja terdapat lima estet getah yang telah diusahakan iaitu Labu, Batu Apoi dan Biang yang terletak di Daerah Temburong. Manakala dua estet lagi iaitu Gadong/Kumbang Pasang dan Berakas yang terletak di Daerah Brunei. Keluasan ladang getah juga meningkat daripada 2,200 ekar pada tahun 1914 
dan kepada 14,747 ekar pada waktu menjelang Perang Dunia Kedua (Pg Khairul Rijal Pg Abdul Rahim, 2007). Dengan adanya industri getah, peluang pekerjaan juga bertambah kepada penduduk tempatan.

Brunei mula mengeksport getah pada tahun 1914 dengan nilai $\$ 1,160$ atau seberat 7,054 paun hasil dari ladang getah Labu Estet dan beberapa kebun getah kecil kepunyaan anak tempatan (Pg Khairul Rijal Pg Abdul Rahim, 2007). Hasil dari eksport getah semakin meningkat selepas itu yang mana pada tahun 1918 nilai eksport dari getah mencapai \$248,919. Tetapi ini belum dapat lagi menjadikan getah sebagai komoditi eksport pertama terpenting di Brunei. Antara tahun 1923 hingga 1930, getah telah muncul sebagai komoditi eksport pertama yang mengatasi nilai eksport ubar. Dalam tempoh berkenaan (1923-1930), nilai eksport telah mencatatkan lebih sejuta ringgit. Ini disebabkan oleh harga getah telah meningkat akibat dari 'American Boom' dan ini juga mendorong para peneroka perladangan di Brunei berebut-rebut untuk mendapatkan permohonan konsesi tanah penanaman semula pokok-pokok getah (Muhaimin Mohamed, 2011).

Selain getah asli, sagu juga memainkan peranan penting dalam ekonomi Brunei pada zaman pemerintahan Residen British. Penduduk Brunei telah memakan sagu sebelum zaman pemerintahan Residen British lagi dan ia pernah menjadi pengganti kepada beras sebagai makanan asasi penduduk Brunei semasa Perang Dunia Pertama. Sagu mula dieksport pada tahun 1908 dengan nilai eksport sebanyak $\$ 11,918$. Semenjak itu sagu menjadi salah satu komoditi eksport Brunei sehingga tahun 1941 dan sagu juga menjadi hasil pertanian Brunei yang ketiga penting selepas getah dan padi. Nilai eksport sagu semakin meningkat dari setahun ke setahun. Pada tahun 1920, nilai eksport sagu berjumlah $\$ 84,512$ semenjak dieksport pada tahun 1908. Kilangkilang memproses sagu mentah menjadi tepung telah mula beroperasi pada tahun 1924 setelah wujudnya kilang-kilang tersebut di Daerah Temburong, Daerah Tutong dan Daerah Belait.

Pentadbiran Residen British juga telah mengembangkan sektor pertanian yang lain seperti padi untuk mengurangkan pergantungan kepada beras yang diimport. Brunei telah mendapatkan benih padi sawah dari Kuala Krian, Perak pada tahun 1909. Ini bertujuan untuk menggalakkan penduduk Brunei terutama kaum Kedayan (salah satu masyarakat di Brunei) menanam padi sawah dari padi tugal (padi huma) yang kurang menguntungkan. Hasil padi mula diperoleh pada tahun 1920 dan pada tahun 1925 sebanyak 600,000 gantang padi telah dapat dihasilkan yang mana dua pertiga daripadanya ialah jenis padi tugal (Muhaimin Mohamed, 2011). 
Selain getah asli, getah jelutong adalah perusahaan dari sektor perhutanan yang menyumbang kepada ekonomi Brunei. Daerah Belait mempunyai banyak perusahaan getah jelutong yang diusahakan oleh kaum Cina dan tenaga buruh pula terdiri dari kaum Iban. Seluas 2,200 ekar tanah telah ditanami dengan pokok jelutong pada tahun 1914 dan 56.6 peratus daripadanya adalah di bawah pengurusan orang-orang Eropah (Muhaimin Mohamed, 2011). Getah jelutong mula dieksport pada tahun 1908 dengan nilai \$753 dan telah meningkat dari setahun ke setahun sehingga tahun 1912 dengan catatan $\$ 70,509$. Eksport getah jelutong merupakan salah satu komoditi eksport penting Brunei di antara tahun 1908 hingga 1913 sebelum getah mula dieksport pada tahun 1914. Keadaan nilai eksport dari getah jelutong telah mengalami turun naik. Jumlah yang tertinggi pernah dicatatkan dari eksport getah jelutong ialah \$295,978 pada tahun 1926.

Kegiatan perlombongan khasnya arang batu juga memberikan sumbangan terhadap ekonomi Brunei sebelum minyak dijumpai. Kegiatan perlombongan telah dipelopori secara meluas oleh orang-orang Eropah yang dibawa masuk oleh pentadbiran Residen British. Syarikat-syarikat Eropah ini bertindak sebagai pemodal untuk menjalankan kegiatan perlombongan di Brunei. Perlombongan ini diberikan tumpuan disebabkan oleh arang batu sangat besar permintaannya di pasaran antarabangsa yang digunakan sebagai tenaga enjin kapal wap.

Jadual 2 menunjukkan kuantiti eksport arang batu di awal lima tahun pengeluarannya yang telah mengalami turun naik iaitu 14,533 tan pada 1906 dan 12,004 tan pada 1910. Pada tahun 1908 tercatat kuantiti terbesar pernah dieksport semasa pemerintahan Residen British iaitu 20,925 tan. Nilai eksport komoditi ini hanya mula tercatat pada tahun 1912 dengan nilai sebanyak $\$ 80,248$ dan terus meningkat dari tahun ke setahun sehingga tahun 1918. Arang batu menjadi komoditi eksport kedua terpenting pada tahun 1906 hingga 1918 (Pg Khairul Rijal Pg Abdul Rahim, 2007), walau bagaimanapun pada tahun 1918 nilai eksport arang batu sebanyak \$413,910 telah mengatasi nilai eksport ubar yang hanya mencatatkan $\$ 362,501$. Nilai eksport arang batu mulai merosot pada tahun 1922 dengan hanya mencatatkan \$104,160 berbanding tahun sebelumnya iaitu $\$ 275,570$.

Brunei juga memajukan sektor perikanannya terutama sekali pada tahun 1918 untuk memenuhi permintaan ikan dan udang kering dengan membuka satu perusahaan udang kering di Pulau Berbunut. Perusahaan ini dianggap kurang penting kerana nilainya yang rendah dalam ekonomi dunia. Eksport udang kering pada tahun 1918 berjumlah \$647. Nilai ini telah 
meningkat dengan drastik kepada \$58,249 pada tahun 1919 dan meningkat lagi kepada \$61,566 pada tahun 1920.

\section{Setelah Minyak Dijumpai}

Dalam tempoh pentadbiran Residen British, satu sejarah penting dalam ekonomi Brunei telah tercatat apabila minyak mula ditemui pada 5 April 1929 di Padang Berawan, Seria di Daerah Belait oleh British Malayan Petroleum Company.

Jadual 2: Kuantiti dan Nilai Eksport Komoditi Utama Sektor Perlombongan 1906-1941

\begin{tabular}{|c|c|c|c|c|c|c|}
\hline \multirow[t]{2}{*}{ Tahun } & \multicolumn{2}{|c|}{ Arang Batu } & \multicolumn{2}{|c|}{ Minyak Mentah } & \multicolumn{2}{|c|}{ Gas Asli } \\
\hline & $\begin{array}{c}\text { Kuantiti } \\
\text { (Tan) }\end{array}$ & $\begin{array}{c}\text { Nilai } \\
(\$) \\
\end{array}$ & $\begin{array}{c}\text { Kuantiti } \\
\text { (Tan) }\end{array}$ & $\begin{array}{c}\text { Nilai } \\
(\$)\end{array}$ & $\begin{array}{c}\text { Kuantiti } \\
\text { (1,000 kaki } \\
\text { Padu) }\end{array}$ & $\begin{array}{c}\text { Nilai } \\
(\$)\end{array}$ \\
\hline 1906 & 14,533 & t.d. & - & - & - & - \\
\hline 1907 & 7,740 & t.d. & - & - & - & - \\
\hline 1908 & 20,925 & t.d. & - & - & - & - \\
\hline 1909 & 13,243 & t.d. & - & - & - & - \\
\hline 1910 & 12,004 & t.d. & - & - & - & - \\
\hline 1911 & t.d. & t.d. & - & - & - & - \\
\hline 1912 & t.d. & 80,248 & - & - & - & - \\
\hline 1913 & t.d. & 145,686 & - & - & - & - \\
\hline 1914 & t.d. & 161,583 & - & - & - & - \\
\hline 1915 & t.d. & 148,730 & - & - & - & - \\
\hline 1916 & t.d. & 206,077 & - & - & - & - \\
\hline 1917 & t.d. & 295,800 & - & - & - & - \\
\hline 1918 & t.d. & 413,910 & - & - & - & - \\
\hline 1919 & 17,363 & 296,621 & - & - & - & - \\
\hline 1920 & 17,000 & 296,003 & - & - & - & - \\
\hline 1921 & 16,210 & 275,570 & - & - & - & - \\
\hline 1922 & 7,440 & 104,160 & - & - & - & - \\
\hline 1923 & 8,941 & 102,820 & - & - & - & - \\
\hline 1924 & 10,337 & 98,202 & - & - & - & - \\
\hline 1925 & 676 & 6,760 & - & - & - & - \\
\hline 1926 & - & - & - & - & - & - \\
\hline 1927 & 52 & 624 & - & - & - & - \\
\hline 1928 & 25 & 300 & - & - & - & - \\
\hline 1929 & - & - & - & - & - & - \\
\hline 1930 & - & - & - & - & - & - \\
\hline 1931 & 57 & 330 & 4,326 & 26,864 & - & - \\
\hline 1932 & 168 & 1,750 & 176,275 & $1,094,663$ & - & - \\
\hline 1933 & 78 & 1,750 & 176,275 & $1,760,861$ & - & - \\
\hline 1934 & 28 & 298 & 371,591 & $2,371,669$ & 792,454 & 113,207 \\
\hline 1935 & 25 & 200 & 441,744 & $2,785,037$ & 464,704 & 65,375 \\
\hline 1936 & 49 & 392 & 446,081 & $2,975,103$ & 940,455 & 131,664 \\
\hline 1937 & 3 & 27 & 550,247 & $3,873,959$ & 747,045 & 104,586 \\
\hline
\end{tabular}




\begin{tabular}{|l|c|c|c|c|c|c|}
\hline 1938 & 54 & 459 & 685,257 & $5,512,549$ & $1,045,621$ & 146,387 \\
\hline 1939 & - & - & 776,027 & $6,566,587$ & $1,181,891$ & 167,942 \\
\hline 1940 & - & - & 851,430 & $7,514,893$ & $1,510,084$ & 215,733 \\
\hline 1941 & - & - & 542,656 & $4,388,182$ & $1,047,136$ & 149,630 \\
\hline
\end{tabular}

Sumber : Jadual 2.4, dalam Pg Khairul Rijal Pg Abdul Rahim (2007, p. 30).

Nota : : t.d. - tiada data.

Brunei mula mengeksport minyak mentah pada tahun 1931. Jadual 2 dan Jadual 3 menunjukkan bahawa eksport pertama minyak mentah agak lembap yang hanya berjumlah 4,326 tan (1931) dengan nilai \$26,864 manakala peratus daripada eksport keseluruhan Brunei hanyalah 5.4 peratus. Ini disebabkan oleh kemelesetan ekonomi dunia pada ketika itu. Tahun berikutnya iaitu 1932, eksport minyak terus meningkat dengan drastik dengan nilai $\$ 1,094,663$ yang berkuantiti sebanyak 176,275 tan. Ini juga terjadi kepada peratus eksport minyak mentah daripada eksport keseluruhan Brunei yang dilihat terus meningkat kepada 72.70 peratus. Gas asli pula mula dieksport pada tahun 1934 sebanyak 792,454 kakipadu dengan nilai $\$ 113,207$. Ini menyebabkan peratus eksport sektor minyak daripada eksport keseluruhan Brunei melonjak naik kepada 93.32 peratus.

Nilai eksport minyak Brunei telah meningkat dari setahun ke setahun sehingga tahun 1940 yang mencatatkan jumlah yang paling tinggi iaitu $\$ 7,514,893$ apabila Brunei berjaya mengeksport sebanyak 851,430 tan minyak. Jumlah eksport gas asli pula mengalami turun-naik pada empat tahun pengeluaran. Tetapi pada tahun 1938 hingga tahun 1940 jumlah eksport gas asli meningkat dari setahun ke setahun. Kuantiti yang dieksport pada tahun 1938 adalah 1,045,621 kaki padu dengan nilai \$146,387 manakala sebanyak 1,510,084 kaki padu dengan nilai $\$ 215,733$ pada tahun 1940. Jumlah telaga minyak yang produktif juga meningkat dari 53 buah pada tahun 1936 kepada 111 buah telaga minyak di Padang Minyak Seria. Ini menjadikan Brunei sebagai pengeluar minyak ketiga terbesar di kalangan British Commonwealth selepas Trinidad dan Burma pada tahun 1936. Walaupun nilai eksport sektor minyak meningkat naik tetapi peratus eksport sektor minyak daripada eksport keseluruhan adalah menurun bermula dari tahun 1935 iaitu dari 93.32 peratus pada tahun sebelumnya kepada 76.84 peratus. Senario ini berlaku sehingga tahun 1937 yang mencatatkan 71.11 peratus. Penurunan ini disebabkan oleh pengaruh dari peningkatan nilai eksport getah asli yang semakin meningkat. Peningkatan nilai eksport getah asli ini disebabkan oleh harga getah naik semula setelah pulih dari kemerosoton. Walau bagaimanapun, sebelum kemasukan Jepun ke Brunei iaitu semasa Perang Dunia Kedua meletus eksport minyak Brunei menurun kepada 542,656 tan yang bernilai 4,388,182. 
Senario yang terjadi kepada eksport minyak mentah juga berlaku kepada gas asli pada tahun 1941 yang menyaksikan penurunan daripada 1,510,084 kaki padu dengan nilai $\$ 215,733$ kepada 1,047,136 kaki padu dengan nilai $\$ 149,630$. Penurunan peratus eksport sektor minyak daripada eksport keseluruhan juga turut menurun setelah naik semula kepada 86 peratus pada tahun 1938. Penurunan peratus eksport sektor minyak daripada eksport keseluruhan berterusan ke tahun 1941 (sebelum Jepun masuk ke Brunei) iaitu 68.50 peratus.

Walau bagaimanapun kecenderungan pentadbiran Residen British dalam usaha cari gali minyak dan pendapatan minyak yang semakin meningkat memberikan implikasi negatif terhadap pengeluaran komoditi lain seperti arang batu, ubar, getah asli, sagu dan produk-produk lain. Misalnya kemerosotan pengeluaran arang batu berterusan sehingga tahun 1938 yang mana nilai eksport hanya \$459 (Pg Khairul Rijal Pg Abdul Rahim, 2007). Manakala nilai eksport paling rendah tercatat adalah pada tahun 1937 dengan hanya memperoleh $\$ 27$.

Jadual 3: Peratus Eksport Sektor Minyak Brunei 1931 - 1941

\begin{tabular}{|c|c|c|c|}
\hline Tahun & $\begin{array}{c}\text { Nilai Eksport Brunei } \\
\text { Keseluruhan } \\
\mathbf{( \$ )}\end{array}$ & $\begin{array}{c}\text { Nilai Eksport Sektor } \\
\text { Minyak } \\
\mathbf{( \$ )}\end{array}$ & $\begin{array}{c}\text { Peratus daripada Eksport } \\
\text { Keseluruhan } \\
\mathbf{( \% )}\end{array}$ \\
\hline 1931 & 501,494 & 26,864 & 5.36 \\
\hline 1932 & $1,505,738$ & $1,094,663$ & 72.70 \\
\hline 1933 & $2,191,037$ & $1,760,861$ & 80.37 \\
\hline 1934 & $3,390,750$ & $3,164,123$ & 93.32 \\
\hline 1935 & $3,709,499$ & $2,850,412$ & 76.84 \\
\hline 1936 & $4,205,270$ & $3,106,767$ & 73.88 \\
\hline 1937 & $5,595,240$ & $3,978,545$ & 81.11 \\
\hline 1938 & $6,580,482$ & $5,658,936$ & 86.00 \\
\hline 1939 & $7,858,878$ & $6,734,529$ & 80.34 \\
\hline 1940 & $9,622,973$ & $7,730,626$ & 68.50 \\
\hline 1941 & $6,624,835$ & $4,537,812$ & \\
\hline
\end{tabular}

Sumber : Data disusun semula dan diperolehi dari Jadual 2.1 - Nilai Perdagangan Brunei 1906-1941 dan Jadual 2.4 - Kuantiti dan Nilai Eksport Komoditi Utama Sektor Perlombongan 1906-1941, dalam Pg Khairul Rijal Pg Abdul Rahim (2007, pp. 24 \& 30).

Setelah minyak dan gas dijumpai dan mula dieksport, peranan ubar dalam eksport Brunei juga semakin menurun dan menjadi ketiga penting selepas getah asli dan minyak. Sebagai contoh pada tahun 1939, nilai eksport ubar hanya berjumlah sebanyak $\$ 62,995$. Manakala, nilai eksport getah selepas minyak dieksport juga didapati menurun. Ia juga disebabkan oleh kejatuhan harga pada tahun 1932 yang mencatatkan 51/2 sen satu paun. Oleh itu nilai 
eksport yang diperoleh dari hasil getah juga merosot iaitu \$104,899 dibanding dengan $\$ 161,204$ pada tahun 1931. Selepas itu harga getah semakin pulih dan nilai eksport getah semakin meningkat kembali sehingga nilai eksport mencatatkan jumlah $\$ 1,240,995$ pada tahun 1937. Manakala nilai eksport tertinggi getah yang pernah dicatatkan dalam tempoh ini (1906-1941) ialah $\$ 1,758,824$ pada tahun 1941 dibanding dengan $\$ 1,503,801$ pada tahun 1940.

Nilai eksport sagu juga terjejas akibat dari penemuan minyak dan gas. Bukan itu sahaja, nilai eksport sagu semakin berkurangan semenjak getah asli mula menjadi eksport terpenting bagi Brunei (Pg Khairul Rijal Pg Abdul Rahim, 2007). Walau bagaimanapun pengeluaran sagu melonjak pulih pada tahun 1940 yang mencatatkan nilai eksport tertinggi mencecah $\$ 102,592$.

Sementara bagi pengeluaran padi walaupun berbagai usaha telah dilaksanakan dalam tempoh berkenaan, Brunei masih bergantung kepada import beras dari luar negeri. Di sektor-sektor lain pula seperti perikanan telah mengalami kemerosotan dan hanya bertahan sehingga tahun 1935 (Pg Khairul Rijal Pg Abdul Rahim, 2007) selepas minyak ditemui. Begitu juga halnya dengan eksport udang kering (Pg Khairul Rijal Pg Abdul Rahim, 2007, p. 39) dan ikan kering didapati merosot dan turun naik. Pendapatan daripada eksport kain tenunan berjumlah \$9,905 pada tahun 1926 dan merosot kepada $\$ 319$ pada tahun 1933 (Muhaimin Mohamed, 2011).

\section{Ekonomi Brunei Semasa Pentadbiran Jepun (1941-1945)}

Tentera Jepun mula mendarat di kepulauan Borneo pada 16 Disember 1941 yang mencetuskan peperangan dengan tentera British untuk menakluki Brunei. Implikasi daripada pentadbiran Jepun selama tiga tahun setengah di Brunei telah banyak membawa perubahan dari aspek sosial, politik dan ekonomi negeri ini. Pendudukan Jepun di Brunei telah menjejaskan perkembangan ekonomi Brunei yang mula berkembang dan meningkat semasa pentadbiran Residen British. Ini ditambah lagi dengan kemelesetan ekonomi dunia akibat dari Perang Dunia Kedua.

Tumpuan pentadbiran Jepun di Brunei dalam bidang ekonomi adalah menghasilkan sumber yang boleh dimanfaatkan bagi tujuan peperangan sahaja. Serangan balas dari Tentera Bersekutu untuk menawan semula Brunei daripada Pendudukan Jepun telah memburukkan lagi keadaan ekonomi Brunei ketika itu. Oleh yang demikian, tumpuan Jepun adalah untuk mempertahankan pendudukannya di bumi Brunei, maka bidang pertanian dan industri minyak menjadi fokus pembangunan ekonomi Brunei. Pengeluaran makanan dalam bidang pertanian dihasratkan untuk keperluan 
makanan tentera Jepun dan penghasilan minyak mentah pula adalah untuk keperluan peperangan.

Setelah bidang pertanian menjadi fokus utama selain industri minyak, pentadbiran Jepun telah mengarahkan penduduk tempatan untuk melipatgandakan usaha bagi memajukan bidang pertanian untuk mengeluarkan makanan. Bagi menampung aktiviti-aktiviti pertanian ini, beberapa kawasan tanah baru telah dibuka supaya kerja-kerja penanaman makanan segera dilaksanakan. Penanaman ubi kayu adalah salah satu sumber makanan yang diusahakan oleh penduduk tempatan. Ubi kayu pada ketika itu amat berguna yang menggantikan bekalan beras yang semakin sukar didapati.

Kekejaman pentadbiran Jepun terserlah apabila Jepun memaksa penduduk Brunei untuk menjadi buruh bagi mengusahakan bidang pertanian sebagai langkah untuk mengatasi masalah kekurangan makanan. Penduduk Brunei dipaksa untuk mengerjakan atau menanam jenis tanaman yang mengeluarkan hasil dengan cepat seperti ubi kayu, keledek, sagu dan sayursayuran untuk menampung hasil makanan. Memandangkan hasil beras tidak mencukupi, ubi kayu merupakan sumber makanan yang kedua penting selepas beras dan oleh itu zaman pendudukan Jepun juga dikenali sebagai 'zaman ubi kayu' (Muhaimin Mohamed, 2011) di mana orang-orang Brunei memakan ubi kayu dengan ikan masin.

Oleh kerana penduduk tempatan digesa untuk bercucuk tanam, mereka yang tinggal di Kampong Ayer terpaksa mengalihkan usaha mereka dari menangkap ikan kepada bidang pertanian bagi menghasilkan makanan. Ini menyebabkan aktiviti menangkap ikan terjejas terutama sekali pada tahun akhir Pendudukan Jepun. Perkara ini juga menyebabkan ramai penduduk Kampong Ayer telah melarikan diri ke kawasan hutan tebal di pedalaman Brunei. Mereka menetap di dalam hutan dan bergantung pada hasil hutan sebagai sumber makanan. Selain itu ada di antara mereka yang telah berpindah ke luar dari Brunei seperti Limbang, Lawas dan Labuan (Pg Khairul Rijal Pg Abdul Rahim, 2007).

Semasa pemerintahan Jepun di Brunei iaitu dalam tempoh tiga setengah tahun, pihak Jepun telah mengeluarkan sebanyak 11,489,000 tong minyak dari Padang Minyak Seria dan Miri (Muhaimin Mohamed, 2011). Daripada jumlah ini dianggarkan kira-kira 1,594,000 tan minyak telah dikeluarkan dari Padang Minyak Seria (Pg Khairul Rijal Pg Abdul Rahim, 2007). Usaha-usaha pentadbiran Jepun mengeluarkan minyak dari telagatelaga minyak adalah semata-mata untuk bekalan peperangan. Ini disebabkan Pentadbiran Jepun lebih menumpukan kepada peperangan bagi mempertahankan wilayah yang didudukinya. 


\section{Ekonomi Brunei Semasa Pentadbiran Residen British (1946-1959)}

Setelah tentera Jepun dapat dikalahkan oleh Tentera Bersekutu British (British Military Administration atau BMA) pada pertengahan tahun 1945, BMA mentadbir Brunei dalam tempoh yang singkat. Ekonomi Brunei pada ketika itu masih lumpuh akibat dari peperangan. Oleh itu pentadbiran BMA hanya menumpukan kepada pemulihan Brunei yang mana antara aspek yang diberikan perhatian ialah memulihkan keamanan dan ketenteraman awam, membangunkan dan membaik pulih kerosakan, menyusun semula pentadbiran dan undang-undang negeri, memberikan bantuan kepada mangsa peperangan dan membasmi penyakit.

Selepas pemulihan dijalankan selama lebih kurang satu tahun, kuasa pentadbiran telah diserahkan semula kepada Residen British seperti sebelum pendudukan tentera Jepun. Brunei telah ditadbir semula oleh pentadbiran Residen British bermula 1946 hingga 1959. Secara keseluruhannya ekonomi Brunei di bawah pentadbiran Residen British dapat dipulihkan semula. Residen British telah mendapatkan bantuan dari Great Britain untuk mengatasi masalah kekurangan makanan yang dialami oleh penduduk Brunei. Bukan itu saja, agensi kerajaan seperti Jabatan Pertanian juga memainkan peranan semula untuk mengendalikan program-program pertanian. Keamanan yang pulih di bumi Brunei selepas peperangan juga menarik semula pelabur-pelabur dari luar negara kembali ke Brunei untuk meneruskan perusahaan mereka dalam sektor pertanian, perhutanan dan perlombongan.

Ciri-ciri ekonomi Brunei pada zaman Residen British kali ini adalah sama dengan ekonomi Brunei pada zaman Residen British sebelum pendudukan Jepun di mana minyak mentah dan getah asli menjadi komoditi keluaran utama. Dalam pada itu terdapat komoditi eksport yang baru iaitu kayu api. Manakala tiga komoditi eksport utama Brunei sebelum ini seperti cutch, sagu dam arang batu telah terjejas dan hanya mampu dibekalkan untuk pasaran tempatan sahaja. Manakala pada akhir tahun 1940-an getah jelutong tidak lagi begitu aktif diusahakan dan ianya hanya menjadi pekerjaan sampingan bagi penduduk pedalaman (Pg Khairul Rijal Pg Abdul Rahim, 2007).

\section{Sektor Minyak}

Selepas peperangan dengan tentera Jepun, kerajaan telah mengambil langkah pemulihan dengan memperbaiki telaga minyak yang rosak. Pada akhir tahun 1946, sebanyak 113 buah telaga minyak yang rosak telah berjaya dipulihkan dan sebanyak 17 buah telaga baru berjaya digerudi. Bukan itu saja, kerja-kerja 
penerokaan minyak dan gas juga ditingkatkan semula. Oleh itu sejak tahun 1945, Syarikat Brunei Shell telah membelanjakan lebih $\$ 650$ juta bagi kerja penerokaan minyak dan gas di Brunei (Muhaimin Mohamed, 2011). Dengan pemulihan dan pelaburan ini, minyak telah berjaya dieksport semula pada tahun 1947 dengan nilai \$29,540,995. (Lihat Jadual 4). Nilai eksport minyak pada tahun 1948 telah meningkat kepada $\$ 47,140,683$ bersamaan dengan peningkatan sebanyak 59.6 peratus dari tahun 1947. Brunei juga meneruskan pengeluaran gas asli yang mana pada tahun 1947, Brunei telah berjaya mengeksport sebanyak 893,344 kaki padu bernilai $\$ 256,500$. Manakala peratus eksport sektor minyak daripada eksport keseluruhan Brunei selepas pulih dari peperangan adalah 95.8 peratus. Peratus eksport sektor minyak ini telah meningkat dari tahun ke tahun yang mencatatkan jumlah tertinggi pada tahun 1952 iaitu 98.37 peratus. Ini kerana nilai eksport minyak mentah dan gas asli semakin meningkat dari tahun ke tahun. Umpamanya nilai eksport gas asli telah meningkat dari setahun ke setahun sehingga tahun 1950 yang mencatatkan sebanyak \$465,694 tetapi menurun sedikit pada tahun 1951. Peningkatan pendapatan dari hasil minyak mentah juga meningkat secara drastik pada tahun 1950 dari $\$ 60,131,144$ pada tahun sebelumnya kepada $\$ 198,210,084$ dengan peratus pertumbuhan sebanyak 229.6 peratus. Tahun 1950, iaitu tahun akhir pemerintahan Sultan Ahmad Tajuddin menyaksikan Seria menjadi sebuah Padang Minyak gergasi dalam Komanwel British, setelah berjaya menghasilkan 30.05 juta tong minyak (Muhaimin Mohamed, 2011). Pencapaian pengeluaran terus meningkat selama dua tahun di mana pada tahun 1952 nilai pendapatan dari minyak mencecah \$270,684,253.

Nilai eksport gas asli kembali meningkat dari tahun 1952 sehingga 1956. Nilai eksport gas asli yang tertinggi dicatatkan pada tempoh ini ialah pada tahun 1956 sebanyak \$694,780, tetapi menurun semula dua tahun berikutnya dan kembali stabil pada tahun 1959 (Pg Khairul Rijal Pg Abdul Rahim, 2007, pp. 85-86). Usaha untuk memajukan pengeluaran gas asli telah dapat dilaksanakan pada 21 Februari 1955 di mana kerajaan Brunei telah berjaya mendirikan loji gas (Tassim Abu Bakar, 2012). Walau bagaimanapun nilai eksport minyak menurun selama dua tahun pada tahun 1953 dan 1954 kepada $\$ 263,961,743$ dan $\$ 262,206,468$. Ini disebabkan oleh terdapatnya dasar yang menghadkan pengeluaran dari beberapa buah telaga minyak untuk menjamin bekalan pada masa hadapan (Pg Khairul Rijal Pg Abdul Rahim, 2007). Dasar ini menyebabkan peratus sumbangan eksport dari sektor minyak menurun pada tahun 1953 kepada 93.59 peratus. Nilai eksport minyak telah meningkat semula pada tahun 1955 kepada $\$ 286,920,405$ dengan pertumbuhan sebanyak 9.4 peratus. 
Jadual 4: Peratus Eksport Sektor Minyak Brunei 1946-1959

\begin{tabular}{|c|c|c|c|c|}
\hline Tahun & $\begin{array}{l}\text { Nilai Eksport } \\
\text { Brunei } \\
\text { Keseluruhan } \\
\text { (\$) }\end{array}$ & $\begin{array}{l}\text { Nilai Eksport Minyak } \\
\text { Mentah } \\
\text { (\$) }\end{array}$ & $\begin{array}{l}\text { Nilai Eksport } \\
\text { Gas Asli } \\
\text { (\$) }\end{array}$ & $\begin{array}{c}\text { Peratus daripada } \\
\text { Eksport } \\
\text { Keseluruhan } \\
(\%)\end{array}$ \\
\hline 1946 & 781,145 & t.d. & t.d. & - \\
\hline 1947 & $31,079,709$ & $29,540,995$ & 256,500 & 95.87 \\
\hline 1948 & $49,252,710$ & $47,140,683$ & 320,795 & 96.36 \\
\hline 1949 & $62,062,791$ & $60,131,144$ & 415,904 & 97.56 \\
\hline 1950 & $205,388,521$ & $198,210,084$ & 465,694 & 96.73 \\
\hline 1951 & $271,838,398$ & $262,813,614$ & 436,226 & 96.84 \\
\hline 1952 & $275,633,204$ & $270,684,253$ & 442,435 & 98.37 \\
\hline 1953 & $282,593,113$ & $263,961,743$ & 514,781 & 93.59 \\
\hline 1954 & $273,476,507$ & $262,206,468$ & 588,458 & 96.09 \\
\hline 1955 & $303,418,823$ & $286,920,405$ & 654,364 & 94.78 \\
\hline 1956 & $330,291,877$ & $309,308,981$ & 694,780 & 93.86 \\
\hline 1957 & $339,984,633$ & $313,737,265$ & 636,132 & 92.47 \\
\hline 1958 & $326,877,860$ & $300,429,192$ & 619,989 & 92.10 \\
\hline 1959 & $310,004,846$ & $292,596,639$ & 634,906 & 94.59 \\
\hline
\end{tabular}

Sumber : Data disusun semula dan diperolehi dari Jadual 3.1 - Nilai Eksport dan Import Brunei 1946-1959, Jadual 3.2 - Nilai Eksport Minyak Mentah Brunei 1946-1959 dan Jadual 3.3 - Nilai Eksport Gas Asli Brunei 1946-1959, dalam Pg Khairul Rijal Pg Abdul Rahim (2007, pp. 83, 84 \& 86).

Nota : t.d. - tiada data.

Nilai pengeluaran minyak mentah terus meningkat kepada $\$ 313,737,265$ pada tahun 1957. Ini adalah nilai yang terbesar pernah dicatatkan pada tempoh pentadbiran Residen British yang kedua. Peningkatan nilai eksport disebabkan oleh bertambahnya jumlah telaga minyak hasil dari usaha mencari gali di beberapa kawasan luar pantai pada tahun 1955 . Usaha berkenaan telah berjaya menggerudi sebanyak 292 buah telaga-telaga baharu. Walau bagaimanapun peratus eksport sektor minyak dari keseluruhan eksport Brunei pada tahun 1957 hanya 92.47 peratus. Penurunan ini disebabkan berlakunya penurunan nilai eksport gas asli serta penurunan nilai eksport Sektor Bukan Minyak seperti getah asli dan getah Jelutong (Pg Khairul Rijal Pg Abdul Rahim, 2007, pp. 88 \& 90). Walaupun demikian nilai eksport minyak telah menurun semula kepada \$300,429,192 iaitu -4.2 peratus pada tahun 1958 dan turun lagi kepada \$292,596,639 iaitu -2.6 peratus pada tahun 1959. Penurunan ini disebabkan oleh beberapa buah telaga minyak yang tidak beroperasi dan telah ditinggalkan. Walau bagaimanapun peningkatan dari nilai eksport gas asli kepada \$634,906 pada tahun 1959 menyebabkan peratus 
sumbangan sektor minyak secara keseluruhan terhadap eksport Brunei meningkat dari tahun sebelumnya kepada 94.59 peratus.

\section{Sektor Bukan Minyak}

Secara keseluruhan peratus sumbangan eksport Sektor Bukan Minyak memanglah kecil jika dilihat dalam Jadual 4 di atas yang mana peratusannya kurang daripada 8 peratus. Sektor pertanian menjadi keutamaan kepada pentadbiran Residen British pada tempoh ini kerana produk-produk pertanian telah mendapat permintaan pasaran antarabangsa. Nilai eksport getah asli pada dasarnya memanglah kecil jika dibanding dengan nilai eksport Brunei secara keseluruhannya, akan tetapi ia menjadi komoditi eksport kedua terpenting pada tempoh ini. Selain itu, keluasan tanaman getah juga telah meningkat daripada 19,450 ekar pada tahun 1948 kepada 36,634 ekar pada tahun 1958 (Pg Khairul Rijal Pg Abdul Rahim, 2007). Walaupun harga getah telah meningkat semula pada tahun 1954 hingga 1956, tetapi nilai eksport getah asli masih pada tahap rendah sehinggalah diakhir tempoh ini. Selain getah, pentadbiran Residen British juga telah memberi tumpuan kepada penanaman padi. Ini disebabkan oleh kebergantungan Brunei kepada import beras semakin meningkat. Pihak kerajaan telah melakukan berbagai usaha untuk memajukan aktiviti penanaman padi yang antara lain adalah dengan memperkenalkan skim "Grow More Food" dan "Padi Test Plots". Percubaan untuk menanam padi pada dua musim juga mengalami kegagalan. Akibatnya Brunei terus mengimport beras dari luar negari.

Selain getah dan padi, perusahaan sagu juga cuba dikembangkan oleh pentadbiran Residen British. Kawasan penanaman sagu pada waktu itu banyak didapati di kawasan paya di Daerah Belait dan Temburong. Usaha ini telah memberikan impak yang positif terhadap perusahaan sagu yang mana keluasan penanaman dan pengeluaran serta eksport sagu telah meningkat. Pada tahun 1948, kawasan menanam sagu ialah 2,046 ekar telah meningkat kepada 2,500 ekar pada tahun 1955 yang dianggarkan boleh menghasilkan sagu sebanyak 2,517 pikul sagu. Manakala jumlah eksport sagu pada tahun 1955 sebanyak 247 pikul telah meningkat kepada 5,027 pikul pada tahun 1959 (Pg Khairul Rijal Pg Abdul Rahim, 2007).

Pentadbiran Residen British juga berusaha mengembangkan sektor perhutanan. Seperti yang diketahui keluaran hutan telah menjadi sumber pendapatan penduduk pedalaman sebelum minyak mentah ditemui. Getah jelutong, kayu api dan kayu balak adalah antara keluaran hutan yang diusahakan pada pentadbiran Residen British waktu itu. Nilai eksport getah jelutong sering mengalami peratus pertumbuhan yang negatif akibat dari 
harga pasaran antarabangsa yang tidak stabil. Nilai eksport tertinggi pernah dicatatkan pada tempoh ini ialah sebanyak \$500,379 pada tahun 1958. Manakala peratus pertumbuhan tertinggi dicatatkan adalah pada tahun 1950 iaitu 208.6 peratus daripada tahun sebelumnya (Pg Khairul Rijal Pg Abdul Rahim, 2007, p. 90). Selain getah jelutong, perusahaan kayu api juga menjadi aktiviti ekonomi Brunei pada waktu itu dan tersenarai sebagai komoditi eksport utama Brunei. Sama seperti hasil getah jelutong, kayu api juga hanya mula dieksport pada tahun 1948 dengan nilai \$39,081. Hong Kong adalah destinasi eksport kayu api Brunei pada zaman itu. Nilai eksport kayu api meningkat dari setahun ke setahun selepas tahun 1948. Keadaan positif ini telah mencapai nilai eksport yang tertinggi pada tahun 1952 berjumlah $\$ 460,950$. Kekurangan tenaga buruh menyebabkan perusahaan kayu api mengalami kemerosotan nilai eksportnya selepas mencapai nilai tertinggi. Pertumbuhan negatif itu berlarutan sehingga tahun 1958 yang mencatatkan nilai eksport hanya berjumlah \$2,675.00 (Pg Khairul Rijal Pg Abdul Rahim, 2007, p. 90). Ini disebabkan oleh munculnya bahan bakar yang lain terutama minyak dan gas di Brunei yang menjejaskan penggunaan kayu api. Pentadbiran Residen British juga mengembangkan perusahaan kayu balak tetapi hanya dengan skala kecil dan hanya mampu memenuhi sebahagian kecil pasaran tempatan sahaja. Pada awal tempoh ini, hanya tiga buah kilang papan telah dibuka di Brunei dan telah meningkat pada tahun 1950-an. Kilang papan meningkat kepada 10 buah pada tahun 1951 dan telah meningkat lagi sebanyak 23 buah pada tahun 1953. Ini menunjukkan bahawa perusahaan ini semakin diberikan perhatian oleh pentadbiran Residen British.

\section{Ekonomi Brunei Semasa Pentadbiran Brunei Berkerajaan Sendiri (1959- 1983)}

Sistem pentadbiran Residen British di Brunei telah berakhir apabila Brunei berjaya mendapat kembali status pentadbiran sendiri atau berkerajaan sendiri (internal self-government) pada 29 September 1959. Oleh itu kuasa pemerintahan penuh dalam negeri secara rasminya dikembalikan semula kepada kerajaan Brunei yang setaraf dengan kemerdekaan dalam negeri. Satu sejarah juga tercatit dalam tempoh ini apabila Sultan Omar Ali' Saifuddien III (SOAS III) telah menyerahkan takhta pemerintahan kepada anakanda baginda, Kebawah Duli Yang Maha Mulia Paduka Seri Baginda Sultan Haji Hassanal Bolkiah Mu'izzaddin Waddaulah, Sultan dan Yang Di-Pertuan Negara Brunei Darussalam pada tahun 1967. Setelah mengambil alih kuasa, baginda telah 
berusaha menyambung rancangan-rancangan pembangunan negara dan projek-projek kerajaan yang telah dirancang oleh ayahanda baginda. Dalam tempoh ini terdapat tiga Rancangan Kemajuan Negara (RKN) Lima Tahun dapat dilaksanakan seperti RKN Kedua dari 1962 hingga 1967, RKN Ketiga dari 1975 hingga 1979, dan RKN Keempat dari 1980 hingga 1984.

Setelah berkerajaan sendiri, ekonomi Brunei mengalami pertumbuhan yang pesat. Pada tahun 1960 KDNK Brunei dianggarkan berjumlah 302.6 juta telah meningkat melebihi $\$ 8.2$ bilion pada tahun 1983. Ekonomi Brunei secara umumnya berkembang pada kadar 14.7 peratus setahun. Sektor minyak merupakan penyumbang utama bagi KDNK. Walau bagaimanapun usaha juga dilakukan untuk mengembangkan sektor bukan minyak sebagai satu langkah dalam mempelbagaikan ekonomi. Kerajaan Brunei telah membahagikan ekonomi Brunei kepada tiga bahagian iaitu sektor pertanian, sektor perindustrian dan sektor perkhidmatan. ${ }^{2}$

\section{Sektor Minyak Dan Gas}

Sumber ekonomi Brunei boleh dikatakan sama keadaannya dengan apa yang berlaku semasa pentadbiran Residen British iaitu sebuah negeri yang ekonominya bersumberkan sektor minyak. Ini menunjukkan bahawa walaupun berbagai-bagai usaha dijalankan untuk mempelbagaikan ekonomi, minyak masih menjadi tunggak utama ekonomi Brunei. Dalam KDNK, sektor minyak telah menyumbang \$243.1 juta pada tahun 1960 dan telah meningkat dengan drastiknya kepada lebih kurang $\$ 9.5$ bilion pada tahun 1980. Minyak mentah, keluaran petroleum dan gas asli merupakan komoditi dalam sektor minyak yang menjadi penggerak utama kepada ekonomi dan kemewahan yang dikecapi Brunei pada zaman Brunei Berkerajaan Sendiri (Pg Khairul Rijal Pg Abdul Rahim, 2007, p. 123).

Nilai eksport minyak mentah pada tahun 1961 berjumlah lebih kurang $\$ 224,000,000$ seperti yang tertera dalam Jadual 5. Nilai eksport bagaimanapun telah menurun sehingga tahun 1963 tetapi mengalami kenaikan semula pada tahun 1964. Hasil dari telaga minyak mentah dari luar pantai yang bermula pada tahun 1963 menyebabkan pertumbuhan positif berkenaan. Bermula dari tempoh itu hasil minyak mentah telah meningkat berterusan dari setahun ke setahun tetapi agak perlahan dari segi peratus pertumbuhannya. Manakala nilai eksport gas asli pada tahun 1962 adalah sebanyak \$748,000 tetapi pertumbuhan nilai eksport tidak begitu memberangsangkan pada 12 tahun pertama yang mana mengalami turun naik. Brunei juga telah berjaya mengeksport keluaran petroleum dan telah berjaya mengatasi nilai eksport gas asli pada tahun 1964 hingga 1972. Nilai eksport keluaran petroleum pada 
tahun 1961 ialah $\$ 233,000$ dan meningkat kepada $\$ 199,959,000$ pada tahun 1983. Tahun 1964 mencatatkan pertumbuhan nilai eksport yang tertinggi dengan kadar 1,201.3 peratus dengan nilai \$3,071,000 dari \$236,000 pada tahun sebelumnya (Pg Khairul Rijal Pg Abdul Rahim, 2007, p. 127). Pada tahun 1967, peratus eksport sektor minyak daripada peratus eksport keseluruhan adalah 96.25 peratus. Peratusan ini menurun sehingga tahun 1972 iaitu 93.92 peratus. Ini disebabkan oleh penurunan dari nilai eksport gas asli dan peningkatan dari sektor bukan minyak seperti sektor perkhidmatan (Pg Khairul Rijal Pg Abdul Rahim, 2007, p. 129). Walau bagaimanapun peratus sumbangan sektor minyak terhadap eksport Brunei semakin meningkat dari 97.12 peratus pada tahun 1973 kepada 99.02 peratus pada 1982, tetapi menurun sedikit pada tahun 1983 kepada 98.90 peratus. Kenaikan secara drastik ini disebabkan oleh peningkatan nilai eksport minyak mentah, gas asli dan juga keluaran petroleum. Peningkatan eksport minyak mentah berlaku apabila Brunei berjaya mengeluarkan 202,000 tong minyak sehari pada tahun 1974 yang mana nilai eksport hampir mencecah $\$ 2$ bilion. Faktor lain adalah dari harga pasaran minyak dunia yang meningkat dari purata US\$3 setong kepada US\$12 setong. Walau bagaimanpun nilai eksport tertinggi yang pernah dicatatkan berjumlah melebihi $\$ 6$ bilion pada tahun 1980 disebabkan oleh kejayaan Brunei menggali kira-kira 650 buah telaga pada tahun 1979. Selain itu faktor penyumbang lain adalah berikutan dengan kekurangan bekalan minyak dunia yang memberikan peluang kepada Brunei untuk mendapatkan pembeli. Peperangan Iran dan Iraq juga memberikan implikasi kepada harga minyak dunia yang menyaksikan lonjakan harga minyak yang drastik pada akhir tahun 1979 dengan purata US\$14 kepada US\$38. Walau bagaimanapun selepas itu iaitu dari tahun 1981 hingga 1983 jumlah eksport minyak menurun. Ini kerana berlakunya lebihan bekalan minyak dunia sehingga Brunei membuat keputusan untuk menghadkan jumlah pengeluaran minyak sebanyak 175,000 tong sehari. Pada akhir tempoh ini iaitu 1983 jumlah eksport minyak adalah 178,000 tong sehari dengan nilai kira-kira $\$ 4$ bilion (Pg Khairul Rijal Pg Abdul Rahim, 2007, p. 124). 
Jadual 5: Peratus Eksport Sektor Minyak Brunei 1960-1983

\begin{tabular}{|c|c|c|c|c|c|}
\hline Tahun & $\begin{array}{l}\text { Nilai Eksport } \\
\text { Brunei } \\
\text { Keseluruhan } \\
\text { (\$) }\end{array}$ & $\begin{array}{c}\text { Nilai Eksport } \\
\text { Minyak } \\
\text { Mentah } \\
\text { (\$ Ribu) }\end{array}$ & $\begin{array}{c}\text { Nilai } \\
\text { Eksport Gas } \\
\text { Asli } \\
\\
\text { (\$ Ribu) }\end{array}$ & $\begin{array}{c}\text { Nilai Eksport } \\
\text { Keluaran } \\
\text { Petroleum } \\
\text { (\$ Ribu) }\end{array}$ & $\begin{array}{c}\text { Peratus } \\
\text { daripada } \\
\text { Eksport } \\
\text { Keseluruhan } \\
(\%)\end{array}$ \\
\hline 1960 & t.d & t.d & t.d & t.d & - \\
\hline 1961 & t.d & 224,104 & 748 & 233 & - \\
\hline 1962 & t.d & 190,061 & 745 & 340 & - \\
\hline 1963 & t.d & 175,748 & 657 & 236 & - \\
\hline 1964 & t.d & 175,790 & 540 & 3,071 & - \\
\hline 1965 & t.d & 190,585 & 555 & 1,463 & - \\
\hline 1966 & t.d & 213,028 & 741 & 2,624 & - \\
\hline 1967 & $248,264,287$ & 235,511 & 1,121 & 2,313 & 96.25 \\
\hline 1968 & $281,420,981$ & 268,356 & 1,095 & 2,848 & 96.76 \\
\hline 1969 & $270,139,966$ & 254,792 & 832 & 2,573 & 95.58 \\
\hline 1970 & $292,063,129$ & 276,538 & 840 & 2,515 & 95.83 \\
\hline 1971 & $323,636,115$ & 304,815 & 537 & 2,520 & 95.13 \\
\hline 1972 & $497,378,827$ & 462,054 & 1,952 & 3,141 & 93.92 \\
\hline 1973 & $852,055,911$ & 762,376 & 46,511 & 18,627 & 97.12 \\
\hline 1974 & $2,388,313,045$ & $1,970,248$ & 291,094 & 86,579 & 98.31 \\
\hline 1975 & $2,494,805,866$ & $1,939,913$ & 424,969 & 97,857 & 98.71 \\
\hline 1976 & $3,293,150,975$ & $2,428,442$ & 685,215 & 146,368 & 98.99 \\
\hline 1977 & $3,999,976,635$ & $2,704,684$ & $1,121,284$ & 126,812 & 98.82 \\
\hline 1978 & $4,195,209,695$ & $2,618,654$ & $1,320,809$ & 165,185 & 97.84 \\
\hline 1979 & $5,796,490,159$ & $3,936,427$ & $1,480,439$ & 285,635 & 98.38 \\
\hline 1980 & $9,852,936,235$ & $6,090,173$ & $3,045,410$ & 577,113 & 98.58 \\
\hline 1981 & $8,591,729,301$ & $4,777,823$ & $3,397,243$ & 322,869 & 98.91 \\
\hline 1982 & $8,153,258,054$ & $4,572,515$ & $3,274,697$ & 226,269 & 99.02 \\
\hline 1983 & $7,170,675,666$ & $4,000,206$ & $2,891,414$ & 199,959 & 98.90 \\
\hline
\end{tabular}

Sumber : Data disusun semula hasil dari sumber Jabatan Perancangan dan Kemajuan Ekonomi Brunei dan dipetik dari Jadual 4.3 - Pengeluaran dan Eksport Minyak Mentah 1960-1983 dan Jadual 4.4 - Nilai dan Peratus Pertumbuhan Eksport Gas Asli dan Keluaran Petroleum Tahun 1960-1983, dalam Pg Khairul Rijal Pg Abdul Rahim. (2007, pp. 124 \& 127).

Nota $\quad$ : ${ }^{\text {t.d. }}$ - tiada data.

Selain itu gas asli juga mengalami pertumbuhan pengeluaran yang ketara berlaku pada tahun 1973 dengan kadar 2,282.7 peratus yang bernilai kira-kira $\$ 46.5$ juta. Peningkatan ini beterusan sehingga tahun 1981 dengan nilai eksport kira-kira \$3.4 bilion pada tahun 1981. Tahun 1981 merupakan nilai eksport yang tertinggi tercatat dalam tempoh ini. Pertumbuhan yang positif ini berpunca dari pembinaan kilang gas cecair asli (LNG) pada tahun 1971. Kilang yang baru beroperasi setahun selepas itu telah menyebabkan peningkatan keluaran gas asli dengan drastik. Nilai eksport selepas tahun 
1981 bagaimanapun telah menurun sehingga tahun 1983, yang mana pada tahun itu mencatatkan sebanyak kira-kira \$2.9 bilion (Pg Khairul Rijal Pg Abdul Rahim, 2007, p. 127). Manakala nilai eksport keluaran petroleum juga mengalami peningkatan dan nilai eksport tertinggi pada tempoh ini sebanyak $\$ 577,113,000$ pada tahun 1980. Ianya turun pada tahun berikutnya sehinggalah pada tahun 1983 kepada $\$ 199,959,000$. Ini berlaku dari pengaruh pengeluaran minyak yang mana Brunei menghadkan pengeluarannya.

\section{Sektor Bukan Minyak}

Sektor bukan minyak yang diambil perhatian oleh kerajaan Brunei pada ketika itu adalah sektor pertanian, sektor perindustrian, dan sektor perikanan. Secara keseluruhannya pada tempoh ini sektor bukan minyak tidak pernah mengatasi sumbangan sektor minyak terhadap KDNK (Pg Khairul Rijal Pg Abdul Rahim, 2007, p. 123). Pada tahun 1964 hingga tahun 1971 peratus sumbangan sektor bukan minyak melebihi 40 peratus, iaitu hampir sama dengan peratus sumbangan dari sektor minyak. Manakala pada tahun 1970 dicatatkan sumbangan tertinggi bagi sektor ini dengan kadar 48 peratus. Selainnya keluaran dari sektor ini boleh dianggap masih jauh ketinggalan dari sektor minyak. Apatah lagi semasa harga minyak melambung naik pada tahun 1974, sumbangan dari sektor bukan minyak semakin ketinggalan jauh kebelakang dari sektor minyak. Keadaan ini berterusan sehingga 1983 apabila sektor bukan minyak hanya memberikan sumbangan secara purata tidak pernah melebihi 20 peratus terhadap KDNK. Pada penghujung tempoh ini nilai eksport sektor bukan minyak semakin mengecil yang disebabkan oleh peningkatan nilai eksport minyak. Pada tahun 1982 dan 1983 walaupun nilai eksport sektor minyak telah menurun tetapi peratus eksport keseluruhannya masih tinggi iaitu 99.02 peratus dan 98.9 peratus. Ini jelas menunjukkan bahawa nilai aktiviti ekonomi sektor bukan minyak semakin menurun. Walau bagaimanapun usaha membangunkan sektor perindustrian mula menampakkan hasil di mana pada tahun 1978 beberapa output telah berjaya dieksport antaranya ais krim; besi; tembaga; aluminium; sisa dan buangan; batu bata; tembikar bangunan; dan perabot (Pg Khairul Rijal Pg Abdul Rahim, 2007, p. 131). Sektor pertanian juga diberikan perhatian dalam RKN lima tahun negara. Walaupun beberapa usaha telah dijalankan, peratus sumbangan sektor pertanian kepada KDNK amatlah jauh ketinggalan, yang mana peratus sumbangan yang tertinggi hanyalah 4.0 peratus pada tahun 1962. Getah asli yang menjadi eksport kedua terpenting Brunei pada zaman sebelum ini, hanya berjaya bertahan sehingga tahun 1963. Kedudukan getah asli diambil oleh komoditi keluaran petroleum dan gas asli. Nilai eksport getah asli semakin 
menurun yang disebabkan oleh harga getah yang semakin menurun. Nilai tertinggi eksport getah asli yang tercatat kira-kira \$3 juta pada awal tempoh ini dan semakin berkurangan sehingga menjadi $\$ 400$ pada tahun 1982. Penurunan juga berlaku kepada nilai eksport kulit lembu dan kerbau dan komoditi lada hitam dan putih. Dalam sektor perhutanan pula, nilai sumbangannya terhadap KDNK sering mengalami turun naik. Ini disebabkan oleh sekatan kerajaan terhadap eksport kayu samada dalam bentuk balak atau digergaji. Eksport utama daripada sektor ini ialah getah jelutong, kayu balak bulat dan kayu bergergaji yang mana didapati nilai eksportnya kurang menggalakkan. Nilai eksport getah jelutong pada tahun 1961 hanya \$338,000 yang juga nilai tertinggi dalam tempoh ini. Tahun terakhir getah jelutong dieksport pada tahun 1977 yang hanya bernilai \$35,000 sahaja. Sementara itu, nilai eksport kayu balak juga telah mengalami kemerosotan pada setiap tahun daripada $\$ 496,000$ pada tahun 1961 menjadi hanya $\$ 12,000$ pada tahun 1976. Selepas itu tidak lagi termasuk dalam komoditi eksport Brunei. Kayu bergergaji tidak disekat oleh kerajaan di mana pengeksportannya telah mencatatkan nilai eksport tertinggi pada tahun 1976 bernilai \$961,000(Pg Khairul Rijal Pg Abdul Rahim, 2007, p. 137).

Manakala sumbangan sektor perikanan terhadap KDNK sering mengalami turun naik. Nilai sumbangan tertinggi hanya $\$ 5.9$ juta pada tahun 1963. Menjelang tahun 1980 barulah menunjukkan perkembangan positif apabila menyumbangkan $\$ 7.6$ juta dan meningkat kepada $\$ 113$ juta pada penghujung tempoh ini. Ini disebabkan oleh peratus pertumbuhan pendaratan ikan yang sering mengalami turun naik dan juga ramai nelayan telah bekerja makan gaji dalam sektor perkhidmatan awam (Pg Khairul Rijal Pg Abdul Rahim, 2007, p. 138). Faktor kos pengimportan ikan yang murah juga menjadi penyebab penurunan jumlah pendaratan ikan.

\section{Ekonomi Brunei Selepas Brunei Mencapai Kemerdekaan (1984-2011)}

Ekoran dari Perjanjian Persahabatan dan Kerjasama di antara Brunei dengan Great Britain pada 7 Januari 1979, Brunei telah kembali menjadi sebuah negara yang merdeka lagi berdaulat mulai 1 Januari 1984. Kemerdekaan Brunei telah mengukuhkan lagi sistem beraja yang diwarisi sejak zaman-berzaman. Ini bermakna kerajaan Brunei telah mengambil alih semula tanggungjawab hal ehwal antarabangsa sebagai mana negara-negara lain di dunia yang berdaulat dan merdeka. Dari sini wujudlah sistem pentadbiran berkementerian di mana baginda sultan sendiri selaku perdana menteri dan ketua pemerintah. 
Ekonomi Brunei selepas merdeka masih bergantung pada sektor minyak seperti minyak mentah, gas asli dan keluaran petroleum. Dalam usaha kerajaan Brunei untuk mempelbagaikan ekonomi, pada tahun 1989, baginda sultan selaku perdana menteri telah menubuhkan satu kementerian baru yang dinamakan Kementerian Perindustrian dan Sumber-Sumber Utama. Jabatan Pertanian, Jabatan Perikanan dan Jabatan Perhutanan yang sebelumnya di bawah Kementerian Pembangunan telah berpindah ke Kementerian Perindustrian dan Sumber-Sumber Utama.

Dari segi pertumbuhan ekonomi zaman selepas kemerdekaan, pertumbuhannya agak perlahan iaitu hanya 0.1 peratus setahun berbanding dengan keadaan sebelum mencapai kemerdekaan iaitu sebanyak 14.7 peratus setahun. Ini disebabkan oleh kemerosotan nilai eksport minyak. Menurut Pg Khairul Rijal Pg Abdul Rahim (2007) dan Brunei Statistical Year Book (2011) KDNK Brunei pada tahun 1984 berjumlah lebih kurang \$8 bilion dan meningkat kepada kira-kira $\$ 8.2$ bilion pada 2003 dan meningkat lagi kepada lebih kurang \$20.6 bilion pada tahun 2011. Dalam pada itu, pertumbuhan sektor bukan minyak pula telah menampakkan perkembangan positif pada kadar 5.2 peratus setahun. Ini menunjukkan bahawa dasar kerajaan untuk mempelbagaikan ekonomi telah memberikan kesan yang positif yang telah dirancang dan dilaksanakan sebelum ini. Namun sumbangan tersebut walaupun dilihat meningkat tetapi masih dianggap kecil jika dibandingkan dengan sumbangan dari sektor minyak kerana ia hanya berperanan untuk mengimbangi kemerosotan pada sektor minyak.

Sepanjang tempoh ini kerajaan Brunei telah berjaya melaksanakan RKN Kelima (1985-1990), RKN Keenam (1991-1995), RKN Ketujuh (1996-2000), RKN Kelapan (2001-2005) dan RKN Kesembilan (2007-2012). Manakala RKN yang sedang berjalan sekarang adalah RKN Kesepuluh. Pada RKN Keenam, peratus pertumbuhan KDNK adalah 3.2 peratus. Peratus pertumbuhan KDNK pada RKN Ketujuh telah turun kepada 1.3 peratus dan naik semula pada RKN Kelapan kepada 2.1 peratus. Manakala, menurut laporan Rancangan Kemajuan Negara Kesepuluh (2012-2017) (2012) pada RKN Kesembilan ekonomi Brunei telah mencatatkan pertumbuhan purata 0.3 peratus.

\section{Sektor Minyak}

Sektor minyak seperti zaman sebelum kemerdekaan, terdiri dari minyak mentah, gas asli dan petroleum masih memainkan peranan penting bagi perkembangan ekonomi negara semasa zaman kemerdekaan. Ini kerana sektor minyak masih menjadi eksport terpenting Brunei. Daripada jumlah keseluruhan nilai eksport Brunei bagi sektor minyak adalah antara 83.27 
peratus hingga 98.74 peratus. Menurut laporan Jabatan Perancangan dan Kemajuan Ekonomi Brunei Darussalam, pada tahun 2011, ekonomi Negara Brunei Darussalam meningkat sebanyak 2.2 peratus berikutan perkembangan sebanyak 2.6 peratus yang dicatatkan dalam tahun 2010. Kedua-dua Sektor Minyak dan Sektor Bukan Minyak masing-masing terus berkembang sebanyak 0.7 peratus dan 3.5 peratus.

Walau bagaimanapun, jika dikaji pada awal zaman kemerdekaan, sumbangan sektor minyak terhadap ekonomi negara telah menurun. Pada tahun 1984, sumbangan sektor minyak terhadap keseluruhan eksport Brunei adalah 98.74 peratus. Peratusan ini semakin menurun dari setahun ke setahun sehingga tahun 2003 kepada 87.77 peratus sahaja (Rujuk Jadual 6). Perkembangan yang tidak begitu memberangsangkan ini berpunca dari kejatuhan nilai eksport minyak mentah. Sebaik sahaja Brunei mendapat kemerdekaan iaitu pada tahun 1984, nilai eksport minyak mentah berjumlah lebih kurang \$3.8 bilion. Nilai eksport tersebut telah jatuh pada tahun 1986 kepada kira-kira $\$ 1.6$ bilion. Ini menjadikan komoditi minyak mentah menjadi eksport kedua Brunei selepas gas asli. Langkah kerajaan Brunei menjalankan dasar penjimatan pengeluaran minyak sehingga kepada paras 150,000 tong sehari secara beransur-ansur telah menyebabkan eksport minyak mentah mengalami kadar pertumbuhan tidak menentu selepas tahun 1986. Pembekalan minyak mentah berlebihan di pasaran dunia pada tahun 1998 telah memburukkan lagi keadaan kadar peratus pertumbuhan minyak mentah dari tahun sebelumnya iaitu sebanyak -30.3 peratus. Apa yang telah berlaku di pasaran dunia pada ketika itu telah menyebabkan kejatuhan harga daripada purata US\$30 setong pada tahun 1984 kepada US\$11 setong pada tahun 1998. Oleh yang demikian, kerajaan Brunei telah meningkatkan pengeluaran minyak dari 157,000 tong sehari pada tahun 1998 kepada 215,000 tong sehari pada tahun 2000. Ini adalah sebagai satu langkah untuk meningkatkan nilai eksport minyak mentah. Strategi ini telah mendatangkan hasil di mana pada tahun 2000, nilai eksport minyak mentah telah meningkat kepada lebih kurang $\$ 3.3$ bilion. Kejayaan ini juga berpunca dari kenaikan semula harga minyak di pasaran dunia dari suku kedua tahun 1999 sehingga mencapai US\$33.53 pada tahun 2000. Keadaan ini berterusan sehingga tahun 2003 yang mana telah mencatatkan nilai eksport sebanyak lebih kurang \$3.7 bilion. Faktor lain yang menyebabkan peningkatan nilai eksport adalah berikutan dengan penemuan padang minyak baharu seperti Mampak pada tahun 1997, Merpati pada tahun 1998 dan Bugan pada tahun 2000.

Nilai eksport gas asli pula telah mengalami kadar pertumbuhan turun naik seperti apa yang telah berlaku kepada minyak mentah. Walau 
bagaimanapun gas asli telah menjadi komoditi eksport terpenting Brunei. Keadaan ini berlaku pada tahun 1986, tahun 1988, tahun 1995, 1997, 1988 dan 2009. Nilai eksport gas asli pada tahun 1987 telah jatuh kepada kira-kira $\$ 1.7$ bilion dari lebih kurang $\$ 2.1$ bilion pada tahun 1986. Nilai eksport hanya berjumlah antara $\$ 1.4$ bilion hingga $\$ 1.8$ bilion sahaja dari 1987 hingga tahun 1999.

Jadual 6: Peratus Eksport Sektor Minyak Brunei 1984-2011

\begin{tabular}{|c|c|c|c|c|c|}
\hline Tahun & $\begin{array}{l}\text { Nilai Eksport } \\
\text { Brunei } \\
\text { Keseluruhan } \\
\text { (\$) }\end{array}$ & $\begin{array}{c}\text { Nilai Eksport } \\
\text { Minyak Mentah } \\
\text { (\$ Ribu) }\end{array}$ & $\begin{array}{l}\text { Nilai Eksport } \\
\text { Gas Asli } \\
\text { (\$ Ribu) }\end{array}$ & $\begin{array}{c}\text { Nilai Eksport } \\
\text { Keluaran } \\
\text { Petroleum } \\
\text { (\$ Ribu) }\end{array}$ & $\begin{array}{c}\text { Peratus } \\
\text { daripada } \\
\text { Eksport } \\
\text { Keseluruhan } \\
(\%) \\
\end{array}$ \\
\hline 1984 & $6,813,939,833$ & $3,840,137$ & $2,852,385$ & 35,714 & 98.74 \\
\hline 1985 & $6,532,888,162$ & $3,552,295$ & $2,782,699$ & 99,259 & 98.49 \\
\hline 1986 & $3,990,101,420$ & $1,619,934$ & $2,110,701$ & 146,672 & 97.17 \\
\hline 1987 & $4,005,605,692$ & $1,953,986$ & $1,772,130$ & 179,673 & 95.51 \\
\hline 1988 & $3,436,446,637$ & $1,460,329$ & $1,717,973$ & 173,596 & 97.54 \\
\hline 1989 & $3,672,610,393$ & $1,719,256$ & $1,645,890$ & 194,975 & 96.94 \\
\hline 1990 & $4,010,146,988$ & $2,040,412$ & $1,605,416$ & 225,218 & 96.53 \\
\hline 1991 & $4,266,965,616$ & $2,024,563$ & $1,896,881$ & 206,199 & 96.73 \\
\hline 1992 & $3,913,370,222$ & $2,036,221$ & $1,562,158$ & 124,856 & 95.14 \\
\hline 1993 & $3,632,297,707$ & $1,785,568$ & $1,591,386$ & 122,664 & 96.35 \\
\hline 1994 & $3,290,455,375$ & $1,549,818$ & $1,412,695$ & 105,783 & 93.25 \\
\hline 1995 & $3,388,275,915$ & $1,475,820$ & $1,561,404$ & 110,691 & 92.91 \\
\hline 1996 & $3,682,708,387$ & $1,702,115$ & $1,582,728$ & 116,899 & 92.37 \\
\hline 1997 & $3,970,490,365$ & $1,650,070$ & $1,859,516$ & 110,342 & 91.17 \\
\hline 1998 & $3,194,319,781$ & $1,149,851$ & $1,557,076$ & 93,943 & 87.68 \\
\hline 1999 & $4,325,144,640$ & $1,875,849$ & $1,632,555$ & 93,057 & 83.27 \\
\hline 2000 & $6,733,520,262$ & $3,352,169$ & $2,532,109$ & 157,282 & 89.72 \\
\hline 2001 & $6,521,757,601$ & $2,893,466$ & $2,814,880$ & 118,102 & 89.34 \\
\hline 2002 & $6,628,696,399$ & $3,139,609$ & $2,603,457$ & 91,877 & 88.03 \\
\hline 2003 & $7,693,777,227$ & $3,759,059$ & $2,964,505$ & 29,601 & 87.77 \\
\hline 2004 & $8,562,713,613$ & $4,912,548$ & $2,914,224$ & - & 91.41 \\
\hline 2005 & $10,397,687,027$ & $6,536,403$ & $3,257,720$ & 71 & 94.20 \\
\hline 2006 & $12,117,128,024$ & $8,157,536$ & $3,514,067$ & 76 & 96.32 \\
\hline 2007 & $11,556,394,128$ & $7,626,532$ & $3,484,179$ & 139 & 96.14 \\
\hline 2008 & $14,942,057,330$ & $7,948,539$ & $6,666,850$ & 104 & 97.81 \\
\hline 2009 & $10,434,873,302$ & $4,974,514$ & $5,049,045$ & 47 & 96.06 \\
\hline 2010 & $12,117,615,192$ & $6,112,222$ & $5,415,508$ & 187 & 95.13 \\
\hline 2011 & $15,678,467,879$ & $7,957,048$ & $7,006,393$ & 129 & 95.44 \\
\hline
\end{tabular}

Sumber : Data disusun semula daripada Jabatan Perancangan dan Kemajuan Ekonomi Brunei, Jadual 5.6 - Nilai Eksport Terpilih, dalam Brunei Darussalam Statistical Year Book (2008, p. 92); Jadual 5.6 - Nilai Eksport Terpilih, dalam Brunei Darussalam Statistical Year Book (2011, p. 94);; dan dipetik daripada Jadual 5.2, Nilai dan Peratus Pertumbuhan Eksport Minyak Mentah, Gas Asli dan Keluaran Petroleum Tahun 1984-2003, dalam Pg Khairul Rijal Abdul Rahim (2007, p. 172). 
Harga pasaran dunia dan jumlah penjualan gas asli yang sering turun naik menyebabkan terjadinya kelembapan ini. Keadaan ekonomi yang tidak memberangsangkan di negara-negara pengimport gas asli seperti krisis ekonomi boleh menyebabkan tekanan ke atas isi padu penjualan gas asli. Misalnya Jepun dan Korea sebagai pengimport utama gas asli Brunei mempraktikan Downturn Quantity Tolerance ke atas kontrak yang mana memberikan implikasi penurunan ke atas jumlah eksport gas asli.

Pada awal tahun 2000, nilai eksport gas asli mula meningkat dengan jumlah lebih kurang \$2.5 bilion. Ini disebabkan oleh pengaruh nilai Dollar Amerika yang mengalami kenaikan. Faktor lain adalah disebabkan oleh kejayaan Brunei mengeksport gas asli ke Sepanyol dan Amerika Syarikat bermula tahun 2002. Perkembangan ini juga menambah kuantiti eksport gas asli. Kesan dari penubuhan sebuah syarikat baru yang bernama Brunei Gas Carriers Sendirian Berhad pada tahun 1999 juga menjadi penyumbang kepada peningkatan nilai eksport gas asli Brunei. Syarikat berkenaan bertanggungjawab untuk menguruskan kapal tangki gas asli dengan muatan 135,000 meter padu.

Selain dari minyak mentah dan gas asli, keluaran petroleum pula menjadi komoditi ketiga terpenting semenjak tahun 1984 hingga 1997. Nilai eksport keluaran petroleum pada tahun 1984 adalah $\$ 35,714,000$ dan terus meningkat kepada $\$ 225,218,000$ pada tahun 1990 merupakan catatan tertinggi bagi tempoh 1984 hingga 2003. Pada tahun 1991, nilai eksport mula menurun yang berjumlah \$206,199,000 dan keadaan ini berterusan hingga tahun 1999 dengan nilai eksport hanya $\$ 93,957,000$. Walau bagaimanapun nilai eksport naik mendadak pada tahun 2000 kepada $\$ 157,282,000$. Secara kasarnya berlaku peningkatan sepanjang tahun 1985 hingga tahun 2002 dimana komoditi ini berjumlah di antara $\$ 91,877,000$ hingga $\$ 225,218,000$. Ini disebabkan oleh peningkatan permintaan ke atas produk petroleum seperti motor gasolin, diesel, kerosin, jet A-1 dan gas petroleum cecair. Pertumbuhan negatif paling tinggi berlaku pada tahun 2003 yang mencatatkan -67.8 peratus yang mana nilai eksport hanya berjumlah $\$ 29,601,000$.

Peratus eksport sektor minyak telah menunjukkan peningkatan semula pada tahun 2004 iaitu sebanyak 91.41 peratus. Ini disebabkan oleh peningkatan nilai eksport minyak kepada $\$ 4.9$ bilion, walaupun ada penurunan sedikit bagi nilai eksport gas asli iaitu dari $\$ 2.96$ bilion pada tahun 2003 kepada \$2.91 bilion pada tahun 2004. Manakala tidak ada eksport dari keluaran petroleum. Peratus eksport sektor minyak terus meningkat pada tahun berikutnya sehingga tahun 2008 yang mencatatkan 97.81 peratus. Walau bagaimanapun ia menurun semula pada tahun berikutnya kepada 
96.13 peratus dan turun lagi pada tahun 2010 kepada 95.13 peratus. Bagaimanapun peratusan eksport sektor minyak naik sedikit pada tahun 2011 kepada 95.44 peratus. Peningkatan peratus eksport sektor minyak pada 2004 seperti yang disebutkan di atas adalah disebabkan oleh peningkatan dari nilai eksport minyak mentah dan gas asli. Nilai eksport minyak mentah terus meningkat pada tahun berikutnya sebanyak kira-kira $\$ 6.5$ bilion tetapi peratus pertumbuhan menurun kepada 24.8 peratus. Nilai eksport minyak mentah semakin meningkat pada tahun 2006 kepada \$8.1 bilion. Dari tahun 2007 sehingga tahun 2011, nilai eksportnya mengalami turun naik. Paling ketara adalah pada tahun 2009 yang mencatatkan nilai eksport yang jatuh menjunam kepada kira-kira $\$ 4.9$ bilion dan peratus pertumbuhan menurun kepada -37.4 peratus. Ini kerana pada tahun 2008 jumlah pengeluaran dan eksport minyak menurun jika dibandingkan dengan tahun 2005. Pada tahun 2008, purata pengeluaran minyak mentah Brunei ialah 175 ribu tong sehari. Dari jumlah itu, 153 ribu tong sehari yang dikeluarkan telah dieksport. Perkara ini berlaku disebabkan oleh kurangnya bilangan telaga minyak yang mengeluarkan minyak iaitu dari 754 buah pada tahun 2007 kepada 746 buah pada tahun 2008 (Brunei Statistical Year Book, 2008, p. 141). Selain itu jumlah eksport minyak pada tahun 2009 semakin menurun dari 154,315 tong sehari pada tahun 2008 kepada 147,689 tong sehari pada tahun 2009 walaupun jumlah telaga minyak bertambah kepada 751 buah pada tahun 2009. Walau bagaimanapun nilai eksport telah meningkat semula pada tahun 2011 dengan nilai lebih kurang $\$ 7.96$ bilion walaupun jumlah pengeluaran hanya 147,909 tong sehari dari sejumlah 735 telaga minyak yang beroperasi. Peningkatan ini disebabkan oleh harga minyak yang meningkat dari 79.27 USD/tong pada tahun 2010 kepada 116.13 USD/tong (Brunei Statistical Year Book, 2011, p. 150).

Peningkatan peratus eksport sektor minyak juga dipengeruhi oleh peningkatan berterusan nilai eksport gas asli dari 2003 sehingga tahun 2008 dengan nilai lebih kurang $\$ 6.7$ bilion. Tahun 2008 mencatatkan peratus pertumbuhan sebanyak 91.3 peratus. Walau bagaimanapun, pada tahun 2009 nilai eksport gas asli telah menurun kepada lebih kurang $\$ 5.0$ bilion dengan mengalami pertumbuhan negatif sebanyak -24.3 peratus. Ini disebabkan oleh penurunan pengeluaran gas asli daripada sekitar 33 ribu meter padu sehari pada tahun 2008 kepada lebih kurang 32 ribu meter padu sehari pada tahun 2009. Selain itu jumlah eksport dan harga gas cecair asli juga menurun pada tahun 2009. Purata harga eksport bagi gas cecair asli pada tahun 2009 adalah 10.46 USD/Juta Btu (British thermal unit) berbanding dengan 12.93 USD/Juta Btu. Tetapi nilai eksport gas asli naik semula pada tahun 2010 dengan nilai lebih kurang $\$ 5.4$ bilion sehingga 2011 yang mencatatkan nilai kira-kira \$7.0 
bilion dengan peratus pertumbuhan sebanyak 29.4 peratus. Menurut laporan Jabatan Perancangan dan Kemajuan Ekonomi, Brunei Darussalam, purata pengeluaran gas asli bagi tahun 2011 adalah kira-kira 35 ribu meter padu sehari yang mana sebahagian besarnya telah dieksport sebagai gas cecair asli ke Jepun (90 peratus) dan selebihnya ke Korea Selatan (10 peratus). Purata harga eksport bagi gas cecair asli (LNG) bagi 2011 adalah kira-kira 16.51 USD/Juta Btu berbanding 11.64 USD/Juta Btu pada tahun 2010. Pengeluaran gas asli bagi tahun 2011 meningkat sebanyak lebih kurang 1.35 juta meter padu sehari berbanding dengan pengeluaran pada tahun 2010. Peningkatan ini adalah akibat dari pengeluaran telaga-telaga luar pantai. Jumlah pengeluaran gas asli daripada telaga-telaga darat adalah dalam keadaan stabil dalam lingkungan paras 1.1 juta meter padu sehari. Selain itu sebanyak 9.1 peratus pengeluaran gas asli telah digunakan untuk penjanaan kuasa elektrik negara (Brunei Statistical Year Book, 2011, p. 146).

Manakala, bagi keluaran petroleum keadaan bertambah buruk dari 2004 hingga ke akhir tempoh ini. Pada tahun 2011 nilai eksport keluaran petroleum hanya berjumlah $\$ 129,000$. Manakala nilai terendah yang pernah tercatat sepanjang tempoh ini ialah $\$ 47,000$ pada tahun 2009.

\section{Sektor Bukan Minyak}

Sektor bukan minyak telah berkembang pada tempoh ini hasil dari perancangan kerajaan yang menitikberatkan supaya ekonomi Brunei tidak bergantung sepenuhnya kepada sektor minyak. Ini juga menunjukkan bahawa dasar mempelbagaikan ekonomi telah mendatangkan hasil yang positif. Walau bagaimanapun pada tahun 1997 dan tahun 1999, peratus sumbangan sektor bukan minyak terhadap KDNK telah sedikit menurun tetapi secara keseluruhannya menunjukkan peningkatan dari setahun ke setahun. Peratus sumbangan kepada KDNK telah meningkat dari 22.2 peratus, lebih kurang $\$ 1.79$ bilion pada tahun 1984 kepada 60.2 peratus, lebih kurang $\$ 4.96$ bilion pada tahun 2003 tetapi menurun selepas itu kepada 38.1 peratus, kira-kira $\$ 5.07$ bilion pada tahun 2004 dan meningkat secara berterusan sehingga tahun 2011 yang menyumbangkan 32.3 peratus atau kira-kira $\$ 6.66$ bilion. Manakala peratus sumbangan tertinggi yang dicatatkan dari tahun 1984 hingga 2011 adalah sebanyak 69.6 peratus iaitu lebih kurang \$4.89 bilion pada tahun 1998 . Peratus sumbangan sektor bukan minyak terhadap KDNK juga telah mengatasi peratus sumbangan sektor minyak bermula pada tahun 1992 dan berterusan sehingga tahun 2003 (Pg Khairul Rijal Pg Abdul Rahim, 2007; Brunei Statistical Year Book, 2008; Brunei Statistical Year Book, 2011). Pertumbuhan sektor bukan minyak ini telah memainkan peranan penting bagi 
mengimbangi pertumbuhan negatif sektor minyak walaupun pertumbuhannya dalam kadar yang perlahan.

Jika dilihat dari segi sumbangan terhadap nilai eksport Brunei keseluruhannya ia juga membuktikan bahawa sektor bukan minyak telah berkembang pada zaman selepas kemerdekaan ini. Ini terbukti daripada penurunan berterusan bagi nilai eksport sektor minyak iaitu 98.74 peratus pada tahun 1984 kepada 87.77 peratus pada tahun 2003. Ini disebabkan oleh peningkatan aktiviti ekonomi dalam sektor perindustrian. Enam komoditi daripada sektor perindustrian ini telah tersenarai menjadi komoditi eksport utama Brunei iaitu ais krim; besi; tembaga; aluminium; sisa dan buangan; batu bata, tembikar bangunan; perabot dan ganti; pakaian; dan simen (Pg Khairul Rijal Pg Abdul Rahim, 2007). Komoditi pakaian bagaimanapun hanya mula dieksport pada tahun 1988 yang mana nilainya terus meningkat dari lebih kurang \$5.1 juta kepada lebih kurang \$398.3 juta pada tahun 2003 (Pg Khairul Rijal Pg Abdul Rahim, 2007, p. 177). Walau bagaimanapun nilai eksport komoditi lain menunjukkan perkembangan yang negatif yang mana pada tahun 2011 hanya mencapai $\$ 7,605,000$. Manakala sektor pertanian masih tidak berkembang walaupun pelbagai usaha telah dilaksanakan oleh kerajaan. Perkembangan negatif bagi tiga komoditi sektor pertanian pada zaman berkerajaan sendiri berterusan pada zaman selepas kemerdekaan. Umpamanya getah asli yang pernah menjadi eksport utama zaman pentadbiran Residen British I hanya dapat dieksport semula pada tahun 1984, 1985, dan 1990 dalam nilai yang sedikit. Perkara yang sama terjadi kepada lada hitam dan lada putih yang hanya dapat dieksport pada awal-awal tahun tempoh ini. Nilai eksport kulit lembu/kerbau juga mengalami turun naik yang mana nilai tertinggi hanya berjumlah $\$ 381,000$ yang dicatatkan pada tahun 2003. Sektor perhutanan juga telah mengalami pertumbuhan yang pada relatifnya kecil sahaja. Walau bagaimanapun sektor perikanan pada zaman kemerdekaan giat dimajukan. Sumbangan sektor ini terhadap KDNK telah meningkat setiap tahun (Pg Khairul Rijal Pg Abdul Rahim, 2007, p. 182). Nilai eksport perikanan pada tahun 2004 adalah \$1,853,000 (Brunei Statistical Year $B o o k, 2008$, p. 92) yang mana meningkat dari tahun sebelumnya iaitu $\$ 852,000$ (Pg Khairul Rijal Pg Abdul Rahim, 2007). Nilai eksport ini semakin meningkat kepada \$9,445,000 pada tahun 2006 iaitu pencapaian yang tertinggi pada tempoh ini. Walau bagaimanapun nilai eksport mula menurun pada tahun 2007 kepada \$5,850,000 dan seterusnya kepada hanya \$629,000 pada tahun 2009. Selepas itu nilai eksport perikanan hanya meningkat sedikit pada tahun berikutnya dan pada tahun 2011 ianya mencatatkan eksport berjumlah $\$ 1,176,000$. 
Perkembangan sejarah ekonomi Brunei ini dapat dilihat seperti pada Jadual 7 yang meliputi enam tempoh masa yang berlainan.

\section{Jadual 7}

Ringkasan Sejarah Perjalanan Ekonomi Brunei Dari Zaman Tradisi
(Sebelum 1906) Hingga 2011

\begin{tabular}{|c|c|c|c|}
\hline \multirow{3}{*}{ ZAMAN } & \multicolumn{3}{|c|}{ SEJARAH INDUSTRI SEKTOR MINYAK } \\
\hline & \multirow{2}{*}{$\begin{array}{c}\text { SEBELUM } \\
\text { MINYAK \& GAS } \\
\text { DIJUMPAI }\end{array}$} & \multicolumn{2}{|c|}{ SETELAH MINYAK \& GAS DIJUMPAI } \\
\hline & & $\begin{array}{c}\text { Peratus Eksport Sektor } \\
\text { Minyak }\end{array}$ & $\begin{array}{c}\text { Peratus Eksport Sektor Bukan } \\
\text { Minyak }\end{array}$ \\
\hline Tradisi & $\begin{array}{l}100 \% \text { eksport dari } \\
\text { kapur barus, kulit } \\
\text { penyu, lilin, gading } \\
\text { gajah, kayu gaharu, } \\
\text { sagu, lada hitam, } \\
\text { rotan \& mutiara. }\end{array}$ & - & - \\
\hline $\begin{array}{l}\text { Residen } \\
\text { British I } \\
\text { 1906-1941 }\end{array}$ & $\begin{array}{l}100 \% \text { eksport dari } \\
\text { ubar, getah asli \& } \\
\text { sagu menjadi } \\
\text { komoditi utama. } \\
\text { Begitu juga dengan } \\
\text { arang batu dan } \\
\text { getah jelutong } \\
\text { semakin } \\
\text { berkembang. }\end{array}$ & $\begin{array}{l}* \text { Minyak mula dieksport } \\
\text { pada } 1931 . \\
* \text { Gas asli mula dieksport } \\
\text { pada } 1935 \text {. } \\
\text { * Peratus eksport meningkat } \\
\text { dari } 5.3 \% \text { kepada } 93.32 \% \text {. } \\
* \text { Purata } 72.19 \% \text {. } \\
\text { * Melonjak naik diawal } \\
\text { eksport dan turun naik di } \\
\text { penghujung tempoh. }\end{array}$ & $\begin{array}{l}\text { Peratus eksport menurun dari } \\
94.64 \% \text { kepada } 6.68 \% \text {. } \\
\text { Purata } 27.81 \% \text {. } \\
\text { * Arang batu menurun \& pupus. } \\
\text { * Ubar menurun. } \\
\text { * Getah asli mengalami turun } \\
\text { naik. } \\
\text { - Sagu mengalami turun naik. } \\
\text { * Getah jelutong meningkat } \\
\text { naik. }\end{array}$ \\
\hline $\begin{array}{c}\text { Pendudukan } \\
\text { Jepun } \\
1941-1946 \\
\end{array}$ & - & - & - \\
\hline $\begin{array}{l}\text { Residen } \\
\text { British II } \\
\text { 1946-1959 }\end{array}$ & - & $\begin{array}{l}\text { * Peratus eksport di antara } \\
92.10 \% \& 98.37 \% \text {. } \\
\text { Purata } 95.32 \% \text {. } \\
\text { * Semakin menyerlah dan } \\
\text { tempat ekonomi } \\
\text { bergantung. }\end{array}$ & $\begin{array}{l}\text { * Peratus eksport di antara } \\
1.63 \% \text { \& } 7.9 \% \text {. } \\
\text { Purata } 4.68 \% \text {. } \\
\text { * Getah asli \& minyak masih } \\
\text { menjadi komoditi eksport } \\
\text { utama tetapi tidak stabil } \\
\text { selepas tahun } 1952 . \\
\text { * Ubar, sagu \& arang batu } \\
\text { terjejas hanya untuk bekalan } \\
\text { tempatan. } \\
\text { * Kayu api juga turut terjejas. }\end{array}$ \\
\hline
\end{tabular}




\begin{tabular}{|c|c|c|c|}
\hline $\begin{array}{l}\text { Berkerajaan } \\
\text { Sendiri } \\
\text { 1959-1983 }\end{array}$ & - & $\begin{array}{l}\text { * Peratus eksport di antara } \\
93.92 \% \text { \& } 99.02 \% \text {. } \\
\text { * Purata } 97.47 \% \text {. } \\
\text { *konomi semakin kukuh } \\
\text { hasil dari sektor minyak. } \\
\text { Keluaran petroleum } \\
\text { menjadi komoditi } \\
\text { tambahan dalam sektor ini. }\end{array}$ & $\begin{array}{l}\text { * Peratus eksport di antara } \\
0.98 \% \text { \& } 6.08 \% \text {. } \\
\text { * Purata } 2.53 \% \text {. } \\
\text { * Sektor ekonomi yang lain mula } \\
\text { terpinggir. } \\
\text { * Getah asli menurun tidak lagi } \\
\text { menjadi komoditi eksport } \\
\text { terpenting. } \\
\text { * Getah Jelutong hanya aktif } \\
\text { pada } 1961-1977 . \\
\text { * Kayu balak hampir pupus. } \\
\text { - Peningkatan } \\
\text { perindustrian. }\end{array}$ \\
\hline $\begin{array}{c}\text { Selepas } \\
\text { Kemerdekaa } \\
\text { n } \\
\text { 1984-2011 }\end{array}$ & - & $\begin{array}{l}\text { * Peratus eksport di antara } \\
83.27 \% \text { \& } 98.74 \% \text {. } \\
\text { * Purata } 93.83 \% \text {. } \\
\text { * Menurun dari tahun } 1984 \\
\text { ke } 2003 \text { tetapi naik semula } \\
\text { pada } 2004 \text { hingga } 2011 . \\
\text { * } 1986 \text { dasar kerajaan dalam } \\
\text { penjimatan pengeluaran } \\
\text { minyak. } \\
\text { 1998 Pembekalan minyak } \\
\text { di pasaran berlebihan / } \\
\text { kejatuhan harga. }\end{array}$ & $\begin{array}{l}\text { Peratus eksport di antara } \\
1.26 \% \text { \& } 16.73 \% \text {. } \\
\text { Purata } 6.17 \% \text {. } \\
\text { Peningkatan nilai eksport } \\
\text { perindustrian terutama sekali } \\
\text { komoditi pakaian. } \\
\text { Eksport perikanan semakin } \\
\text { meningkat tetapi menurun } \\
\text { semula tahun } 2007 . \\
\text { Kayu balak bergergaji masih } \\
\text { dieksport dalam beberapa } \\
\text { tahun. } \\
\text { Lain-lain tidak lagi tersenarai } \\
\text { dalam eksport negara. }\end{array}$ \\
\hline
\end{tabular}

Sumber : Kajian lapangan.

\section{Kesimpulan}

Perjalanan ekonomi Brunei tergantung kepada sistem pentadbiran semasa dan siapa yang memerintah. Semasa zaman Residen British, eksploitasi sumber ekonomi menjadi tumpuan dan kurang penumpuan diberikan terhadap pembangunan. Walau bagaimanapun kebijaksanaan Sultan Ahmad Tajuddin, membolehkan hasil jualan minyak dimanfaatkan untuk membayar hutang dan melaksanakan pembangunan. Zaman pendudukan Jepun pula telah menghancurkan ekonomi Brunei. Setelah berkerajaan sendiri, Sultan Omar 'Ali Saifuddien membangunkan Brunei dengan begitu pesat dan menjadi makmur. Pembangunan ini berterusan apabila Sultan Haji Hassanal Bolkiah mengambil alih kuasa sehinggalah sekarang. 


\section{Nota Hujung}

${ }^{1}$ Ubar digunakan bagi menyamak kulit binatang dan mencelup pukat ikan dan layar kapal.

${ }^{2}$ Sektor pertanian terdiri daripada pertanian dan perburuan, perhutanan dan pembalakan, dan perikanan; Sektor perindustrian terdiri daripada perlombongan termasuk penggalian dan perkilangan, elektrik dan pembinaan; Sektor perkhidmatan yang terdiri daripada perdagangan (borong dan runcit), restoran dan hotel, pengangkutan, penstoran dan perhubungan, perusahaan bank dan kewangan, insurans, harta rumah tangga dan perniagaan, pemilikan tempat kediaman dan perkhidmatan masyarakat, sosial dan perseorangan.

\section{Rujukan}

Abu Bakar, T. (2012). Permasalahan Perpindahan Petempatan Penduduk Dari Air ke Darat di Negara Brunei Darussalam, 1906-2006. Tesis Ph.D., Jabatan Pengajian Asia Tenggara, Fakulti Sastera dan Sains Sosial Universiti Malaya, Kuala Lumpur.

Brunei Statistical Year Book. (2003). Department of Economic Planning and Development, Prime Minister's Office, Brunei Darussalam.

Brunei Statistical Year Book. (2008). Department of Economic Planning and Development, Prime Minister's Office, Brunei Darussalam.

Brunei Statistical Year Book. (2011). Department of Economic Planning and Development, Prime Minister's Office, Brunei Darussalam.

Jamit, J. (2012). Perkembangan Pentadbiran Kewangan Brunei Di Bawah Sistem Residen - 100 Tahun Hubungan Brunei-British 1906-2006. Pusat Sejarah Brunei.

Mohamed, M. (2011). Pemerintahan Sultan Ahmad Tajuddin 1924-1950, Kerajaan Masyarakat dan Perubahan. Pusat Sejarah Brunei.

Perancanaan Kemajuan Jangka Panjang Negara Brunei Darussalam, Wawasan Brunei 2035; Rangka Strategi dan Dasar Bagi Pembangunan (OSPD) 2007-2017; Rancangan Kemajuan Negara (RKN). (2007-2012). Jabatan Percetakan Kerajaan, Jabatan Perdana Menteri, Negara Brunei Darussalam.

Rahim, K. R. P. H. A. (2007). Teknologi menangkap ikan di Negara Brunei

Darussalam, 1906-2003. Penerbit Universiti Malaya.

Rancangan Kemajuan Negara Kelapan, 2001-2005. Negara Brunei Darussalam. Rancangan Kemajuan Negara Kesepuluh, 2012-2017. (2012). Negara Brunei

Darussalam, Jabatan Perancangan dan Kemajuan Ekonomi, Jabatan Perdana Menteri. 
Rancangan Kemajuan Negara Ketujuh, 1996-2000. Negara Brunei Darussalam. Rancangan Kemajuan Negara Yang Keenam, 1991-1995. (1993). Negara Brunei Darussalam.

Rancangan Kemajuan Negara Yang Kelima, 1986-1990. Unit Perancang Ekonomi, Kementerian Kewangan, Negara Brunei Darussalam.

Ranchangan Kemajuan Negara, 1962 - 1966. Negeri Brunei.

Ranchangan Kemajuan Negara, 1962 - 1966. Negeri Brunei.

Ranchangan Kemajuan Negara, 1975-1979. Negeri Brunei.

Ranchangan Kemajuan Negara, 1980-1984. Yunit Peranchang Ekonomi, Pejabat Setiausaha Kerajaan Brunei, Negeri Brunei. 